\title{
Tomato 12 Immune Receptor Can Be Engineered to Confer Partial Resistance to the Oomycete Phytophthora infestans in Addition to the Fungus Fusarium oxysporum
}

\author{
Artemis Giannakopoulou, ${ }^{1}$ John F. C. Steele, ${ }^{2}$ Maria Eugenia Segretin, ${ }^{3}$ Tolga O. Bozkurt, ${ }^{1,4}$ Ji Zhou, ${ }^{1,5}$ \\ Silke Robatzek, ${ }^{1}$ Mark J. Banfield, ${ }^{2}$ Marina Pais, ${ }^{1}$ and Sophien Kamoun ${ }^{1}$ \\ ${ }^{1}$ The Sainsbury Laboratory, Norwich Research Park, NR4 7UH Norwich, United Kingdom; ${ }^{2}$ Department of Biological Chemistry, \\ John Innes Centre, Norwich Research Park, Norwich, NR4 7UH, United Kingdom; ${ }^{3}$ INGEBI-CONICET, Ciudad Autónoma de \\ Buenos Aires, C1428ADN, Argentina; ${ }^{4}$ Imperial College, Faculty of Natural Sciences, Department of Life Sciences, South \\ Kensington Campus, London SW7 2AZ, United Kingdom; and ${ }^{5}$ The Genome Analysis Centre, Norwich Research Park, NR4 \\ 7UH Norwich, United Kingdom
}

Submitted 17 April 2015. Accepted 7 September 2015.

Plants and animals rely on immune receptors, known as nucleotide-binding domain and leucine-rich repeat (NLR)containing proteins, to defend against invading pathogens and activate immune responses. How NLR receptors respond to pathogens is inadequately understood. We previously reported single-residue mutations that expand the response of the potato immune receptor R3a to AVR3a ${ }^{\mathrm{EM}}$, a stealthy effector from the late blight oomycete pathogen Phytophthora infestans. I2, another NLR that mediates resistance to the wilt-causing fungus Fusarium oxysporum f. sp. lycopersici, is the tomato ortholog of R3a. We transferred previously identified R3a mutations to I 2 to assess the degree to which the resulting $I 2$ mutants have an altered response. We discovered that wild-type $I 2$ protein responds weakly to AVR3a. One mutant in the N-terminal coiled-coil domain, $\mathbf{I}^{\mathrm{I141N}}$, appeared sensitized and displayed markedly increased response to AVR3a. Remarkably, $\mathbf{I 2}^{\mathbf{I 1 4 1 N}}$ conferred partial resistance to $P$. infestans. Further, $I^{1141 \mathrm{~N}}$ has an expanded response spectrum to $F$. oxysporum f. sp. lycopersici effectors compared with the wild-type $\mathbf{I} 2$ protein. Our results suggest that synthetic immune receptors can be engineered to confer resistance to phylogenetically divergent pathogens and indicate that knowledge gathered for one NLR could be exploited to improve NLR from other plant species.

Plant diseases are one of the main threats to modern human life, and the need for sustainable crop disease resistance is becoming increasingly urgent (Fisher et al. 2012; Pennisi 2010). Plants have evolved various disease resistance mechanisms to defend against pathogens. Sustainable crop

Nucleotide sequence data is available in the GenBank database under accession number KR108299.

Corresponding authors: S. Kamoun; E-mail:

sophien.kamoun@sainsbury-laboratory.ac.uk; and

M. Pais: E-mail: marina.pais@sainsbury-laboratory.ac.uk

*The $\boldsymbol{e}$-Xtra logo stands for "electronic extra" and indicates that seven supplementary figures and one supplementary table are published online.

@ 2015 The American Phytopathological Society improvement based on these mechanisms often involve resistance $(R)$ genes: plant loci that encode immune receptors (Cook 2000; Jones et al. 2014; Michelmore et al. 2013). One challenge is to engineer plants with broad-spectrum disease resistance (i.e., that can defend against a wide spectrum of pathogens). Although this can be achieved by pyramiding multiple immune receptors with different pathogen resistance spectra, single $R$ genes that function against multiple pathogens do occur. One example is the tomato gene $M i-1.2$, which confers resistance to pathogens from different phyla: arthropods (aphids and whiteflies) and a nematode (Atamian et al. 2012; Nombela et al. 2003). Cf-2, an extracellular tomato immune receptor, also mediates resistance to both the fungus Cladosporium fulvum and the root-parasitic nematode Globodera rostochiensis (Lozano-Torres et al. 2012). Moreover, in Arabidopsis, RPS4 and RRS1 mediate resistance to the bacteria Pseudomonas syringae and Ralstonia solanacearum but also to the fungus Colletotrichum higginsianum (Birker et al. 2009; Deslandes et al. 2003; Gassmann et al. 1999; Narusaka et al. 2009). However, pathogens continuously evolve new races that overcome immunoreceptor-specific mediated disease resistance. The challenge for plant breeders and biotechnologists is to generate new resistance gene specificities rapidly enough to keep up with pathogen evolution. Engineering synthetic wide-spectrum immune receptors that target more than one pathogen is one approach to rapidly deliver agronomically useful resistance genes.

Plants resist pathogenic invasion through cell surface and intracellular immune receptors that recognize pathogen-secreted molecules and activate immune responses (Dodds and Rathjen 2010; Win et al. 2012). The largest family of intracellular immune receptors is the nucleotide-binding (NB) leucine-rich repeat (LRR) (or NLR) protein family, an important element of defense against pathogens in both plants and animals (Jacob et al. 2013; Maekawa et al. 2011b). In plants, NLR proteins recognize effectors: pathogen-secreted molecules that normally modulate host cell processes to the benefit of the pathogen (Bozkurt et al. 2012; Dodds and Rathjen 2010; Hogenhout et al. 2009; Win et al. 2012). NLR tend to recognize one or a limited number of effectors, resulting in NLR-triggered immunity or effectortriggered immunity (Dodds and Rathjen 2010; Jones and Dangl 2006; van Ooijen et al. 2007; Win et al. 2012). There are two major classes of NLR proteins, depending on their $\mathrm{N}$ terminal domains: 
coiled-coil (CC)-NB-LRR (or CNL) proteins, with a predicted CC structure, and Toll/interleukin-1 receptor (TIR)-NB-LRR (or TNL) proteins, with a TIR domain (Andolfo et al. 2014; Pan et al. 2000). The NB domain, also known as NB-ARC (shared by the mammalian protein Apaf-1, plant resistance proteins, and the nematode Caenorhabditis elegans Ced-4 protein), is the most conserved among the NLR proteins and is thought to act as a switch between the resting (ADP-bound) and activated (ATPbound) state of the receptor (Maekawa et al. 2011b; Takken and Goverse 2012; Takken et al. 2006; Tameling et al. 2006). The C-terminal LRR domain tends to be more polymorphic, with the number and length of the LRR being highly variable between different NLR proteins (Takken and Goverse 2012). Activation of NLR receptors usually results in a localized cell death response known as the hypersensitive response (HR), which is associated with restricting pathogen colonization of the host tissue (Spoel and Dong 2012; Win et al. 2012).

The CNL class of NLR has dramatically expanded in the Solanaceae (nightshade) botanical family (Andolfo et al. 2014). In tomato, for example, 18 distinct clades of CNL genes are present in every chromosome, whereas only a single TNL clade occurs (Andolfo et al. 2014). Two agronomically important genes occur in the Solanaceae CNL-8 clade. $R 3 a$ from the wild potato Solanum demissum confers resistance to specific strains of the late blight oomycete pathogen Phytophthora infestans that carry the avirulence effector AVR $3 \mathrm{a}^{\mathrm{KI}}$ (Armstrong et al. 2005; Bos et al. 2006). In tomato, the $R 3 a$ ortholog $I 2$ confers resistance against race 2 of the ascomycete fungus Fusarium oxysporum f. sp. lycopersici, the agent of tomato wilt disease (Ori et al. 1997; Simons et al. 1998; Takken and Rep 2010). F. oxysporum f. sp. lycopersici secretes the effector AVR2, which activates I2-mediated immunity. Single-amino-acid mutations of AVR 2 in race 3 of the pathogen abolish recognition by I2 and overcome I2-mediated disease resistance (Houterman et al. 2009; Takken and Rep 2010). A current challenge is to breed $R$ genes that respond to the stealthy AVR2 variants.

$S$. demissum $R 3 a$ is one of the first late blight $R$ genes to be bred in cultivated potato (Gebhardt and Valkonen 2001; Hawkes 1990; Huang et al. 2005). The R3a immune receptor strongly responds to the $P$. infestans RXLR-type hosttranslocated AVR3 $3 \mathrm{a}^{\mathrm{K} 80 / 1103}$ effector (referred to as AVR3a ${ }^{\mathrm{KI}}$ ) but weakly to AVR3 $\mathrm{a}^{\mathrm{E} 80 / \mathrm{M} 103}$ (AVR3 $\mathrm{a}^{\mathrm{EM}}$ ), which differs in only two amino acids in the mature protein (Armstrong et al. 2005; Bos et al. 2006). P. infestans strains that carry $A v r 3 a^{K I}$, either in a homozygous or heterozygous configuration, are avirulent on $R 3 a$ potatoes (Armstrong et al. 2005; Bos et al. 2006, 2009; Chapman et al. 2014; Segretin et al. 2014). P. infestans strains homozygous for $A v r 3 a^{E M}$ are virulent on $R 3 a$ and have increased in frequency in $P$. infestans populations since the 19th century, to become dominant in many potato-growing regions of the world (Chowdappa et al. 2013; Cooke et al. 2012; Li et al. 2013b; Yoshida et al. 2013, 2014). This prompted Segretin et al. (2014) to expand the response spectrum of R3a to AVR $3 \mathrm{a}^{\mathrm{EM}}$ by random mutagenesis. Eight single-amino acid mutants, termed R3a+, gained response to AVR $3 \mathrm{a}^{\mathrm{EM}}$ while retaining the ability to respond to AVR3a ${ }^{\mathrm{KI}}$ (Segretin et al. 2014). Six of these R3a+ mutations locate to the LRR domain, one in the NB-ARC and one in the CC. The two mutants in the CC and NB-ARC domains (R3a $\mathrm{a}^{\mathrm{I} 148 \mathrm{~F}}$ and $\mathrm{R} 3 \mathrm{a}^{\mathrm{N} 336 \mathrm{Y}}$, respectively) showed further gain-of-response to PcAVR3a4, an AVR3a homolog from the pepper pathogen $P$. capsici. Segretin et al. (2014) proposed that these mutants are sensitized, "trigger-happy" mutants, with a lower threshold for activation of the NLR receptor and, therefore, conferring enhanced response to weak elicitors. However, the R3a+ mutants, and similar multiple-site R3a mutants described by Chapman et al. (2014), did not translate in enhanced resistance to $P$. infestans isolates homozygous for the Avr $3 a^{E M}$ allele, indicating that the observed gain-of-response in the cell death assay was insufficient for late blight resistance.

In this study, we took advantage of the relatively high sequence similarity between $S$. demissum R3a and its tomato ortholog I2 to test the extent to which gain-of-function mutants identified in one NLR can be transferred to a homologous receptor from another plant species. This study was based on the observation that two residues mutated in the R3a+ mutants, $\mathrm{R} 3 \mathrm{a}^{\mathrm{I} 148 \mathrm{~F}}$ and $\mathrm{R} 3 \mathrm{a}^{\mathrm{N} 336 \mathrm{Y}}$, are conserved in I2 (Huang et al. 2005), and our hypothesis that these residues are hotspots for sensitized phenotypes in the R3a/I2 class of NLR. However, transfer of the two R3a+ mutations to I2 resulted in a loss-of-response for $\mathrm{I}^{\mathrm{I} 141 \mathrm{~F}}$ and autoactivity for $\mathrm{I} 2^{\mathrm{N} 330 \mathrm{Y}}$. We then reasoned that other amino-acid substitutions at the same positions might yield the desired phenotype and, therefore, generated I2 mutant proteins carrying all possible amino acids in positions 141 and 330. Remarkably, one mutant, $\mathrm{I} 2^{\mathrm{I} 141 \mathrm{~N}}$, displayed expanded response to both AVR $3 \mathrm{a}^{\mathrm{KI}}$ and AVR3a ${ }^{\text {EM }}$ and conferred partial resistance to $P$. infestans strains carrying either of the AVR3a variants. In addition, I $2^{\mathrm{I} 141 \mathrm{~N}}$ responded to two stealthy $F$. oxysporum f. sp. lycopersici AVR2 effector variants that evade response by the wild-type $\mathrm{I} 2$ receptor. This work demonstrates that synthetic NLR receptors can confer expanded pathogen effector and disease resistance spectra, and that knowledge of one NLR can be exploited to improve homologous NLR from other plant species.

\section{RESULTS}

12 responds weakly to $\mathrm{AVR} 3 \mathrm{a}^{\mathrm{KI}}$.

Given that $I 2$ and $R 3 a$ are orthologous genes, we first determined whether I 2 responds to the two AVR3a variants from $P$. infestans. We co-expressed I2 with each of the AVR3a isoforms using Agrobacterium tumefaciens-mediated transient transformation (agroinfiltration) in the model plant Nicotiana benthamiana and scored for hypersensitive cell death phenotypes. We found that I2 responds weakly to AVR3a ${ }^{\mathrm{KI}}$ (HR index typically between 0.5 and 1.2 on a scale of 0 to 3 at 6 days postinfiltration [dpi]) (Fig. 1; Supplementary Fig. S1). Occasionally, I2 showed a weak response to AVR3a ${ }^{\mathrm{EM}}$ (HR index less than 0.5) (Fig. 1). Both AVR3a variants were expressed alone in $N$. benthamiana to exclude any possibility of weak autoactivity of these constructs (Supplementary Fig. S2). No cell death reaction was seen upon transient expression of either AVR3a variant, suggesting that the I2/AVR3a cell death is specific. These findings, together with the high amino-acid sequence similarity between R3a and I2, prompted us to test the possibility that transferring previously identified R3a+ mutations to I2 expands the response profile of this NLR receptor.

\section{Homology models of the NB-ARC domain highlights conserved $\mathrm{R} 3 \mathrm{a}+$ residues.}

Although the overall similarity between R3a and I2 is relatively high (83\% amino-acid similarity), the NB-ARC domain displays the highest sequence conservation (Huang et al. 2005) (Fig. 2A). We generated structural models of the conserved CC and NB-ARC domains using four online prediction programs (IntFOLD2, iTASSER, Phyre2, and SWISS-MODEL).

For the CC domain, three of the prediction programs (iTASSER, Phyre2, and SWISS-MODEL) identified the CC domain of the barley CNL protein MLA10 as the top-scoring template for modeling of the I2 CC-domain. Interestingly, IntFOLD2 (Buenavista et al. 2012; McGuffin et al. 2015) produced a model based on the CC domain of the potato CNL protein Rx (Fig. 2B), which adopts a distinct structure, quite different at the three-dimensional level from MLA10. Despite these different models (either of which could be valid), in each of the structures, the I2 I141 residue is consistently positioned to the C-terminus of the defined CC units and, therefore, is 
predicted to be located at an interdomain region between the $\mathrm{CC}$ and NB-ARC domains (Supplementary Fig. S3).

For the NB-ARC domain, the structures of the equivalent regions of Apaf-1 (Vaughn et al. 1999), DARK (Pang et al. 2015), and CED-4 (Yan et al. 2005) were consistently used as templates by the programs for modeling, with high confidence scores. We choose to use the models based on Apaf-1, because the crystal structure of this template has been determined to the highest resolution and the residues forming the ATPase active site are appropriately positioned. As would be predicted from the modeling of the R3a NB-ARC domain (Segretin et al. 2014), the I 2 N330 position maps to the junction of the NB and ARC1 regions (Fig. 2B), near the NB site and adjacent regions that have been implicated in nucleotide exchange events in plant NB-LRR proteins and associated with activity (van Ooijen et al. 2008).

The structural models indicate that the two gain-of-function positions in the I2 CC and NB-ARC domain occur in interdomain regions, and mutations at these positions may affect the overall conformational dynamics of the protein. Therefore, we proceeded with the generation of I 2 mutants in these positions.

\section{The $\mathrm{I}^{\mathrm{I141F}}$ and $\mathrm{I}^{\mathrm{N} 330 \mathrm{Y}}$ mutants}

are nonfunctional and autoactive, respectively.

We generated mutants of $\mathrm{I} 2$ that are equivalent to $\mathrm{R} 3 \mathrm{a}^{\mathrm{I} 148 \mathrm{~F}}$ and $\mathrm{R} 3 \mathrm{a}^{\mathrm{N} 336 \mathrm{Y}}$, the R3a+ mutations in the CC and NB-ARC domains. We assayed these I 2 mutants, $2^{\mathrm{I}}{ }^{141 \mathrm{~F}}$ and $\mathrm{I} 2^{\mathrm{N} 330 \mathrm{Y}}$, with $\mathrm{AVR} 3 \mathrm{a}^{\mathrm{KI}}$ and AVR3a ${ }^{\mathrm{EM}}$ using agroinfiltration in $N$. benthamiana. $\mathrm{I}^{\mathrm{I}}{ }^{141 \mathrm{~F}}$ showed a loss-of-response because it did not trigger any cell death when co-expressed with either one of the AVR3a isoforms (Fig. 3). I2 ${ }^{\mathrm{N} 330 \mathrm{Y}}$ was autoactive; it triggered strong cell death (HR index 3) even in the absence of effector proteins (Fig. 3). These results indicate that the specific R3a+ amino-acid substitutions do not confer desirable phenotypes to I 2 but highlight the importance of these two positions for $\mathrm{I} 2$ activity.

\section{I2 mutants at positions 141 and 330.}

We hypothesized that additional amino-acid substitutions at I2 positions 141 and 330 might yield an expanded response to AVR3a. To test this, we randomly mutagenized I2 codons 141 and 330 (Fig. 4). Next, we cloned mutagenized $I 2$ molecules in the binary vector pk7WG2 (Karimi et al. 2002) under the transcriptional control of the Cauliflower mosaic virus 35S promoter, and transformed them into A. tumefaciens. We obtained mutants representing all different amino acids for position 330, whereas we generated a library with only 12 amino acids for position 141 . We screened the mutant clones by co-expression with the AVR3a isoforms in N. benthamiana and grouped the cell death phenotypes in four categories: strongly autoactive (HR index $=3$ in the absence of effectors), loss-of-response (no HR phenotype), similar profile to wild-type I2, and gain-ofresponse (expanded response to AVR $3 \mathrm{a}^{\mathrm{EM}}$ ). Substitutions of the Asn in position 330 with Cys, His, Leu, Tyr, Arg, Thr, Ser, Val, Trp, Phe, Met, and Ile resulted in autoactive mutants; Glu,

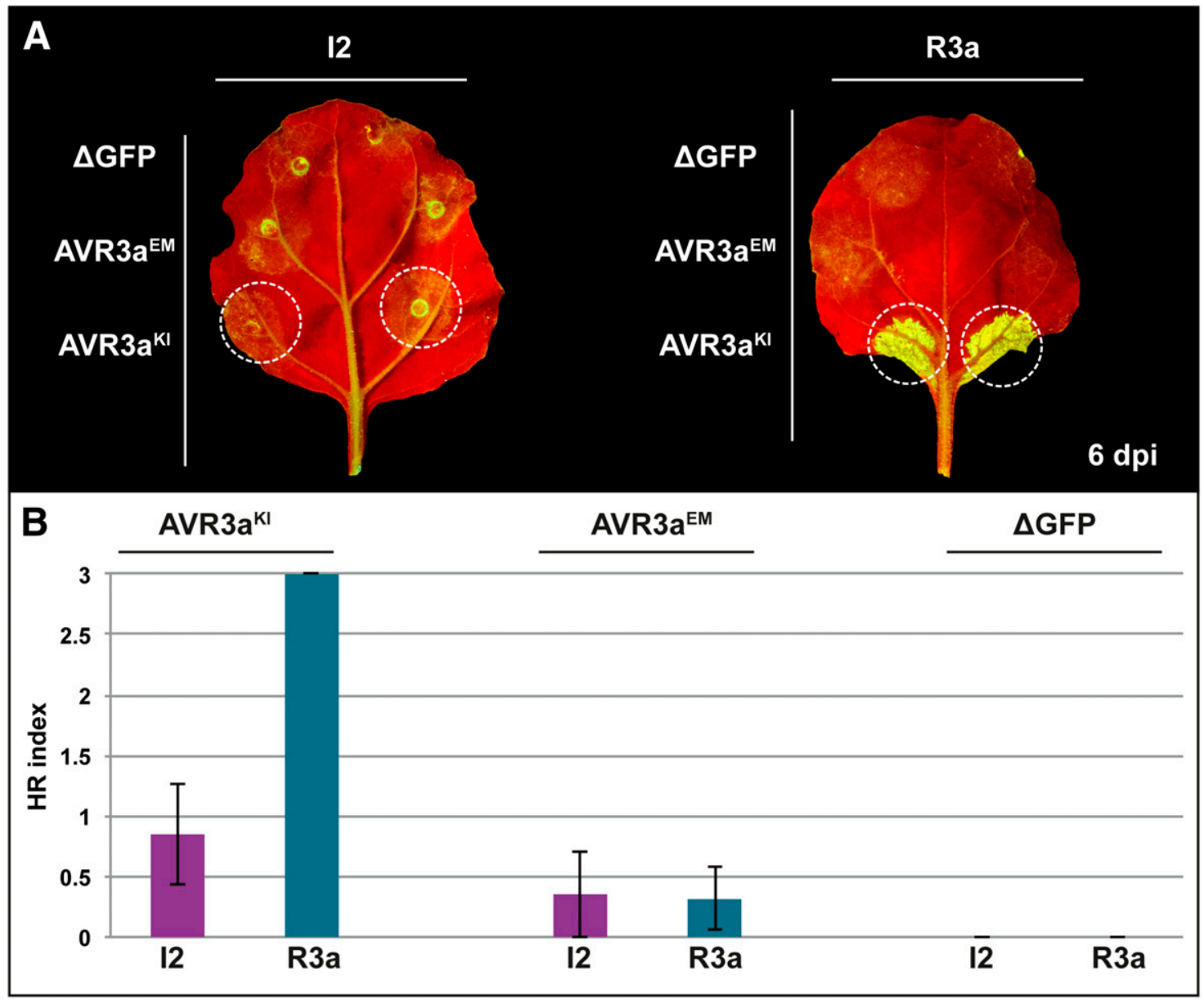

Fig. 1. Tomato resistance protein $\mathrm{I} 2$ responds to $\mathrm{AVR} 3 \mathrm{a}^{\mathrm{KI}}$ from Phytophthora infestans. A, Hypersensitive response (HR) phenotypes of wild-type I2 after co-expression with the P. infestans AVR3a variants in Nicotiana benthamiana leaves. Wild-type I2 was under transcriptional control of the Cauliflower mosaic virus $35 \mathrm{~S}$ promoter and $\mathrm{AVR} 3 \mathrm{a}^{\mathrm{KI}}$, AVR $3 \mathrm{a}^{\mathrm{EM}}$, or a truncated version of green fluorescent protein $(\triangle \mathrm{GFP})$ were expressed from a Potato virus $X$-based vector. The picture was taken at 6 days postinfiltration (dpi). B, HR indices corresponding to the experiment described in A. Values scored at 6 dpi are plotted. Bars represent the average of 20 replicas for each combination of constructs; error bars represent standard deviation. 
R3a MEIGLAVGGAFLSSALNVLFDRLAPHGDLLNMFQKHKDHV 40

I2 MEIGLAVGGAFLSSALNVLFDRLAPNGDLLNMFRKHKDHV 40

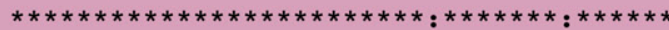

R3a KLLKKLEDILLGLQIVLSDAENKQASNRHVSQWFNKLQNA 80

I2 KLLKKLKMTLRGIQIVLSDAENKQASNPSVRDWLNELRDA 80 $* * * * * *: * *: * * * * * * * * * * * * * * \quad *: *: *: *:: *$ EDVID

R3a VDGAENLIEQVNYEALRLKVEGQHQNLAETSNQQVSDLNL 120

I2 VDSAENLIEEVNYEALRLKVEGOHONFSETSNQQVS---- 116 $\star * . * * * * * *: * * * * * * * * * * * * * * * *:: * * * * * * * *$

R3a CFSDDFFLNIKDKLEETIETLEVLEKOIGRLGLKEHFGST 160

12 ---DDFFLNIKDKLEDTIETLKDLQEQIGLLGLKEYFDST 153 $\star * * * * * * * * * * *: * * * * *: *:: * * * * * * * *: * . * *$

R3a KQETRTP

12 KLETRRP

$* \star * * *$

\section{NB-ARC}

hhGREXE

R3a STSLVDDSD IFGRQNDIEDLIDRLLSEDASGKKRTVVPIV

I2 STSVDDESDIFGRQSEIEDLIDRLLSEGASGKKLTVVPIV $* * *: *: * * * * * * * .: * * * * * * * * * * * . * * * * * * * * * * *$

$$
\text { P-loop RNBS-A }
$$

R3a GMGGLGKTTLAKAVYNDERVQIHFGLKAWFCVSEAFDAFR 247

I2 GMGGQGKTTLAKAVYNDERVKNHFDLKAWYCVSEGFDALR 240 $* * * * * * * * * * * * * * * * * * *: * * . * * * *: * * * * . * * *: *$

R3a ITKGLLQEIGSFDLK-ADDNLNQLQVKLKERLKGKKFLIV 286 I2 ITKELLQEIGKFDSKDVHNNLNQLQVKLKESLKGKKFLIV 280 $* * * * * * * * * . * * * \ldots: * * * * * * * * * * * * * * * * * * * *$ Walker B RNBS-B / Sensor I

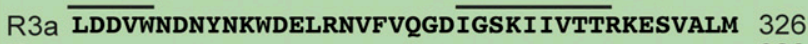

I2 LDDVWNENYNEWNDLRNIFAOGDIGSKIIVTTRKDSVALM 320 $* * * * * *: * * *: *:: * * *: * . * * * * * * * * * * * * * *: * * * * *$ RNBS-C

R3a MGNEQISMDNLSTESSWSLFKTHAFENMGPMGHPELEEVG 366

I2 MGNEQIRMGNLSTEASWSLFQRHAFENMDPMGHPELEEVG 360 $* * * * * * * . * * * * *: * * * * *: * * * * * * . * * * * * * * * * * *$ NBं ${ }^{*}{ }^{* *}$ ARC $_{1}^{*}$

\section{GLPL}

R3a KQIAAKCKGLPLALKTLAGMLRSKSEVEEWKRILRSEIWE 406

I2 RQIAAKCKGLPLALKTLAGMLRSKSEVEEWKRILRSEIWE 400

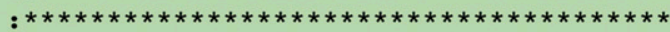
RNBS-D

R3a I PHNDILPALMLSYNDLPAHLKRCFSFCAIFPKDYPFRKE 446

12 I PHNDILPALMLSYNDLPAHLKRCFSFCAIFPKDYPFRKE 440 $* * * * * * * * * * * * * * * * * * * * * * * * * * * * * * * * * * * * * * * *$ ARC1 ARC2

R3a QVIHLWIANGLVPQEDVIIEDSGNQYFLELRSRSLFERVP 486

I2 QVIHLWIANGLVPVKDEINQDLGNQYFLELRSRSLFEKVP 480 $* * * * * * * * * * * *:: * *: * * * * * * * * * * * * * * * *: * *$ MHD

R3a NPSQGNTENLFLMHDLVNDLAQIASSKLCIRLEESQGSHM 526

I2 NPSKRNIEELFLMHDLVNDLAQLASSKLCIRLEESQGSHM 520 $* * *: * *: * * * * * * * * * * * * *: * * * * * * * * * * * * * * * * *$

R3a LEQSQHLSYSMGYGGEFEKLTPLYKLEQ

12 LEQCRHLSYSIGFNGEFKKLTPLYKLEQ $* * * .: * * * * *: *: . * * *: * * * * * * * * * *$

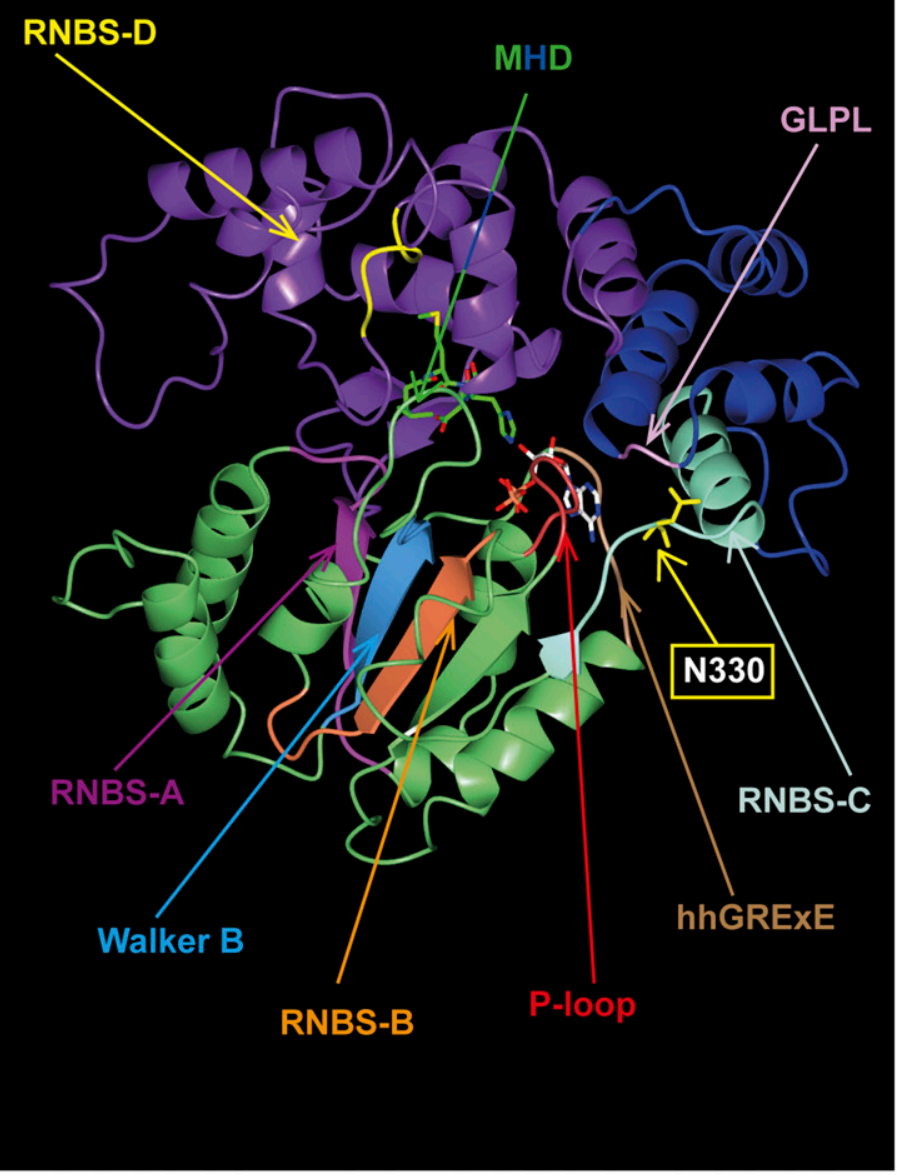

Fig. 2. I2 and R3a are highly similar in the N-terminal region. A, Protein sequence alignment of the CC and NB-ARC domains of I2 and R3a. The amino-acid positions that were subjected to mutation are highlighted in yellow. Conserved R-protein motifs in the NB-ARC domain are overlaid according to van Ooijen et al. (2007). Blue lines delimit the three subdomains of the NB-ARC: NB, ARC1, and ARC2. B, Structural model of the CC and NB-ARC domain of I2. Models were generated by remote homology modeling using the INTFold2 server (Buenavista et al. 2012; McGuffin et al. 2015). The CC domain is shown in pink, and NB-ARC is shown in three different colors depending on the subdomain: NB (green), ARC1 (purple), and ARC2 (blue). Amino acids corresponding to the single-residue I2 mutations are shown in yellow stick representation. Carbon atoms of ATP are shown in white. Locations of NLR-protein motifs are indicated with arrows. 
Pro, and Asp gave a loss-of-response phenotype; and Lys, Gln, and Ala had a response profile similar to the wild-type I2 (Fig. 4). Substitution of the Ile in position 141 with Tyr resulted in an autoactive mutant; Arg, Pro, Val, Ala, Lys, Leu, Thr, and Asp showed a loss-of-response phenotype. Interestingly, I2 ${ }^{1141 \mathrm{~N}}$, which carries a substitution of Ile to Asn in position 141, responded more strongly to AVR3 ${ }^{\mathrm{EM}}$ compared with the wildtype I2 (Fig. 5).

\section{A single amino-acid change} expands the response of 12 to AVR3a ${ }^{\mathrm{EM}}$.

To determine the extent to which the single-site I141N mutation in the CC domain of $\mathrm{I} 2$ expands its response profile to the AVR $3 \mathrm{a}^{\mathrm{EM}}$ variant, we co-expressed $\mathrm{I}^{\mathrm{I}}{ }^{\mathrm{I} 41 \mathrm{~N}}$ with both AVR3a isoforms using $N$. benthamiana agroinfiltration. $2^{\mathrm{I} 141 \mathrm{~N}}$ responded to AVR3a ${ }^{\mathrm{EM}}$ (HR index between 2.5 and 3 on a scale of 0 to 3 ), and also exhibited a stronger response to AVR $3 \mathrm{a}^{\mathrm{KI}}$ when compared with wild-type I2 (HR index approximately 2 versus 0.7 for the wild type) (Fig. 5). I $2^{\mathrm{I} 141 \mathrm{~N}}$ also exhibited a weak response in the absence of effector (HR index approximately 1 ), which is lower than the response to the two AVR3a variants. These results indicate that a single-amino-acid change in the $\mathrm{CC}$ domain of I2 (I141N) expanded its response profile to AVR $3 \mathrm{a}^{\mathrm{EM}}$ and increased response of the receptor to the AVR $3 \mathrm{a}^{\mathrm{KI}}$ isoform.

To examine whether the activity of the $\mathrm{I} 2^{\mathrm{I} 141 \mathrm{~N}}$ mutant protein extends to additional AVR3a variants besides AVR $3 \mathrm{a}^{\mathrm{KI}}$ and AVR $3 \mathrm{a}^{\mathrm{EM}}$, we tested both the $\mathrm{I} 2$ wild type and the $\mathrm{I} 2^{\mathrm{I}}{ }^{\mathrm{a} 1 \mathrm{~N}}$ mutant for their response to selected AVR3a mutants with amino-acid substitutions at position 80 in AVR $3 \mathrm{a}^{\mathrm{K} 80 \times / \mathrm{I} 103}$ and AVR3a ${ }^{\mathrm{E} 80 \times / \mathrm{M} 103}$ (Bos et al. 2009). I2 ${ }^{\mathrm{I} 141 \mathrm{~N}}$ showed expanded response to all of the mutants tested (Supplementary Fig. S4).

\section{$12^{\mathrm{I141N}}$ protein accumulates}

at different levels compared with wild-type $\mathbf{I}$.

To determine the effect of the I141N mutation on the stability of the I 2 protein, we performed Western blot assays using a polyclonal antibody raised against the CC domain of R3a. We collected samples at 2,3 , and $5 \mathrm{dpi}$, because we reasoned that

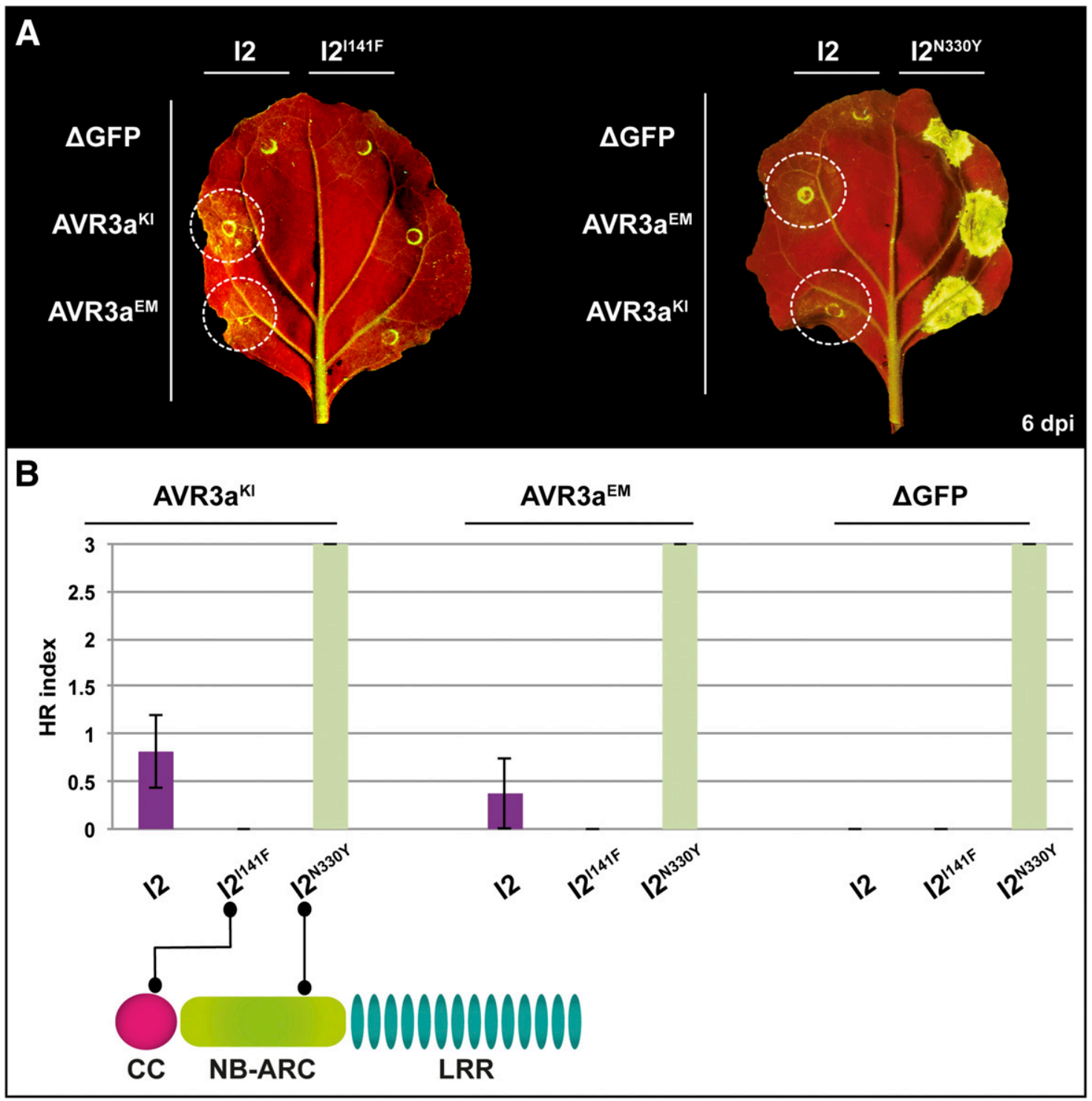

Fig. 3. $\mathrm{I} 2$ mutants carrying the precise $\mathrm{R} 3 \mathrm{a}+$ singe-amino-acid mutations in the $\mathrm{CC}$ and NB-ARC domains show a loss-of-response and an autoactive phenotype, respectively. A, Hypersensitive response (HR) phenotypes of wild-type $\mathrm{I} 2, \mathrm{I}^{\mathrm{I}}{ }^{\mathrm{I} 41 \mathrm{~F}}$, and $\mathrm{I} 2^{\mathrm{N} 330 \mathrm{Y}}$ after co-expression with the Phytophthora infestans AVR3a variants in Nicotiana benthamiana leaves. Wild-type $I 2$ and $I 2$ mutants were under transcriptional control of the Cauliflower mosaic virus $35 \mathrm{~S}$ promoter and AVR $3 \mathrm{a}^{\mathrm{KI}}, \mathrm{AVR} 3 \mathrm{a}^{\mathrm{EM}}$, or a truncated version of green fluorescent protein $(\triangle \mathrm{GFP})$ were expressed from a Potato virus $X$-based vector. Pictures were taken at 6 days postinfiltration (dpi). B, HR indices corresponding to the experiment described in A. Values scored at 6 dpi are plotted. The cartoon indicates the approximate positions of the mutations. Bars represent the average of 16 replicas for each combination of constructs; error bars represent standard deviation. 
this range of time points would allow us to detect potential differences in the protein levels between $\mathrm{I} 2$ and $\mathrm{I} 2^{\mathrm{I} 141 \mathrm{~N}}$. Interestingly, at 2 and $5 \mathrm{dpi}$, wild-type $\mathrm{I} 2$ yielded a more intense signal than the $\mathrm{I} 2^{\mathrm{I} 141 \mathrm{~N}}$ mutant (Fig. 6). The loss-of-response mutant protein $\mathrm{I} 2^{\mathrm{I} 141 \mathrm{~T}}$ was used as an additional control in this experiment and only yielded a weak signal at 5 dpi (Fig. 6). Additional analysis of the remaining loss-of-response mutants at the N-terminal part of I2 showed that all of them are expressed (Supplementary Fig. S5). Of the I2 loss-of-response mutants tested, I2 $2^{\mathrm{I} 141 \mathrm{D}}, \mathrm{I} 2^{\mathrm{I} 141 \mathrm{~T}}, \mathrm{I} 2^{\mathrm{I} 141 \mathrm{~L}}, \mathrm{I} 2^{\mathrm{I} 141 \mathrm{~K}}, \mathrm{I} 2^{\mathrm{I} 141 \mathrm{~V}}, \mathrm{I} 2^{\mathrm{I} 141 \mathrm{~F}}$, and $\mathrm{I} 2^{\mathrm{N} 330 \mathrm{E}}$ all accumulated to lower level than the wild-type $\mathrm{I} 2$ protein.

\section{$\mathrm{R3a}^{\mathrm{I148N}}$ has a response profile similar}

\section{to that of wild-type R3a.}

To investigate whether the I141N mutation in the CC domain of $\mathrm{I} 2$ could also alter the response profile of $\mathrm{R} 3 \mathrm{a}$, we introduced this mutation in R3a to generate the R3 $\mathrm{a}^{\mathrm{I} 148 \mathrm{~N}}$ mutant. We then co-expressed $\mathrm{R} 3 \mathrm{a}^{\mathrm{I} 148 \mathrm{~N}}$ with the AVR3a variants using agroinfiltration assays in $N$. benthamiana and scored for the HR. The response of $\mathrm{R} 3 \mathrm{a}^{\mathrm{I} 148 \mathrm{~N}}$ to the two AVR3a isoforms was similar to that of wild-type R3a, because a potent HR was detected only when the protein was co-expressed with AVR3a $\mathrm{KI}^{\mathrm{K}}$ (HR index approximately 3) (Supplementary Fig. S6). As previously reported (Bos et al. 2009), a weak response was
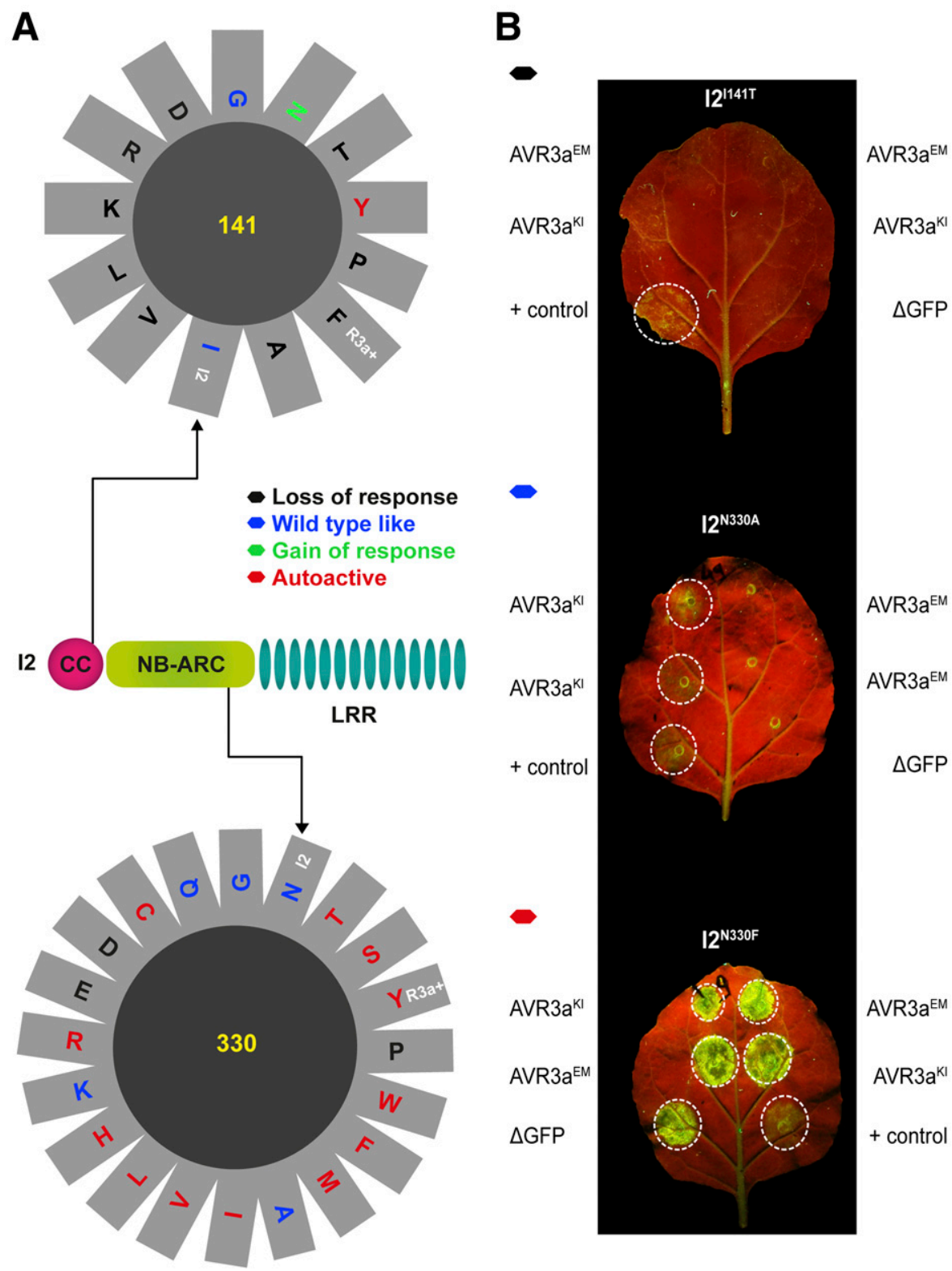

Fig. 4. I2 mutant libraries carrying randomized amino acids at positions 141 and 330 . The full-length $I 2$ coding sequence (3,801 bp) was used as template for a polymerase chain reaction-based mutagenesis targeted to the corresponding coding sequence positions. Amplification products were cloned in the binary vector pK7WG2 (under transcriptional control of the Cauliflower mosaic virus $35 \mathrm{~S}$ promoter) and transformed into Agrobacterium tumefaciens. The library was screened for gain-of-response phenotypes by coagroinfiltration in Nicotiana benthamiana of the I 2 mutant clones with Phytophthora infestans AVR3a ${ }^{\mathrm{KI}}$ and AVR $3 \mathrm{a}^{\mathrm{EM}}$ expressed from a Potato virus $X$-based vector. $\triangle \mathrm{GFP}=$ truncated version of green fluorescent protein. A, Amino-acid substitutions are colored according to the response phenotypes obtained: black (loss of response), blue (wild-type like), green (gain of response), and red (autoactive). Wild-type amino acids at these positions and amino acids corresponding to the R3a+ mutants are indicated by the I2 and R3a+ labels, respectively. B, Hypersensitive response phenotypes of selected $\mathrm{I} 2$ mutants generated in this library $\left(\mathrm{I}^{\mathrm{I}}{ }^{\mathrm{I} 41 \mathrm{~T}}, \mathrm{I} 2^{\mathrm{N} 330 \mathrm{~A}}\right.$, and $\mathrm{I} 2^{\mathrm{N} 330 \mathrm{~F}}$ ) after co-expression with the P. infestans AVR3a variants in $N$. benthamiana leaves, representing a loss-of-response, wild-type like, and autoactive phenotypic example, respectively. Positive control (+) represents I2 wild-type co-expressed with AVR $3 \mathrm{a}^{\mathrm{KI}}$ in each leaf. 
sometimes observed when the wild-type R3a protein was coexpressed with the AVR3a ${ }^{\mathrm{EM}}$ variant, a trend that was also observed for the $\mathrm{R} 3 \mathrm{a}^{\mathrm{I} 148 \mathrm{~N}}$ mutant $(\mathrm{HR}$ index $<0.2)$. These results further indicate that, even though the 141/148 amino-acid position in the CC domain is important for the activities of I2 and R3a, different amino-acid substitutions are necessary to expand the response spectrum of these immune receptors.

$12^{\mathrm{I141N}}$ confers partial resistance

to a $P$. infestans strain expressing AVR3a ${ }^{\mathrm{EM}}$.

To determine the degree to which the expanded response profile of $\mathrm{I}^{\mathrm{I} 141 \mathrm{~N}}$ translates into a wider resistance spectrum, we performed infection assays in $N$. benthamiana leaves expressing $\mathrm{I} 2$ and $\mathrm{I} 2^{\mathrm{I} 141 \mathrm{~N}}$ with different strains of $P$. infestans. We expressed $\mathrm{I} 2$ and $\mathrm{I} 2^{\mathrm{I} 141 \mathrm{~N}}$ using A. tumefaciens-mediated transformation in leaves of 3- to 4-week-old $N$. benthamiana plants. Approximately $15 \mathrm{~h}$ after agroinfiltration, we inoculated infiltrated leaves with $P$. infestans zoospore suspensions. We first examined the effect of the wild-type I2 protein on $P$. infestans strain NL00228 homozygous for Avr3a ${ }^{K I}$ (Zhu et al. 2012) or strain
88069 homozygous for $A v r 3 a^{E M}$ (van West et al. 1998). I2 expression restricted infection by $P$. infestans NL00228, as illustrated by smaller lesion sizes compared with those observed in leaves expressing a control construct (Fig. 7). In contrast, I2 did not impact infection by strain 88069 , resulting in no significant differences in lesion sizes (Fig. 7). Remarkably, the I2 $1141 \mathrm{~N}$ mutant protein restricted infection by both strains of $P$. infestans. In more detail, the effect of $\mathrm{I}^{\mathrm{I} 141 \mathrm{~N}}$ on the $P$. infestans NL00228 strain was at a level similar to the wild-type I2 (Fig. 7). Restriction of $P$. infestans 88069 growth in leaves expressing $\mathrm{I} 2^{\mathrm{I} 141 \mathrm{~N}}$ was evident because smaller lesions developed compared with those developed in leaves expressing a control construct (Fig. 7; Supplementary Fig. S7). These findings suggest that the $\mathrm{I} 2^{\mathrm{I} 141 \mathrm{~N}}$ mutant has an expanded resistance profile to $P$. infestans relative to the $\mathrm{I} 2$ wild-type receptor.

$\mathrm{I}^{\mathrm{I141N}}$ responds to $F$. oxysporum $\mathrm{f}$. sp. lycopersici stealthy effectors AVR2 ${ }^{\mathrm{V}>M}$ and AVR2 ${ }^{\mathrm{R}}>\mathrm{H}$.

We also tested the extent to which $\mathrm{I} 2^{\mathrm{I} 141 \mathrm{~N}}$ has altered response to AVR2 effectors of $F$. oxysporum f. sp. lycopersici

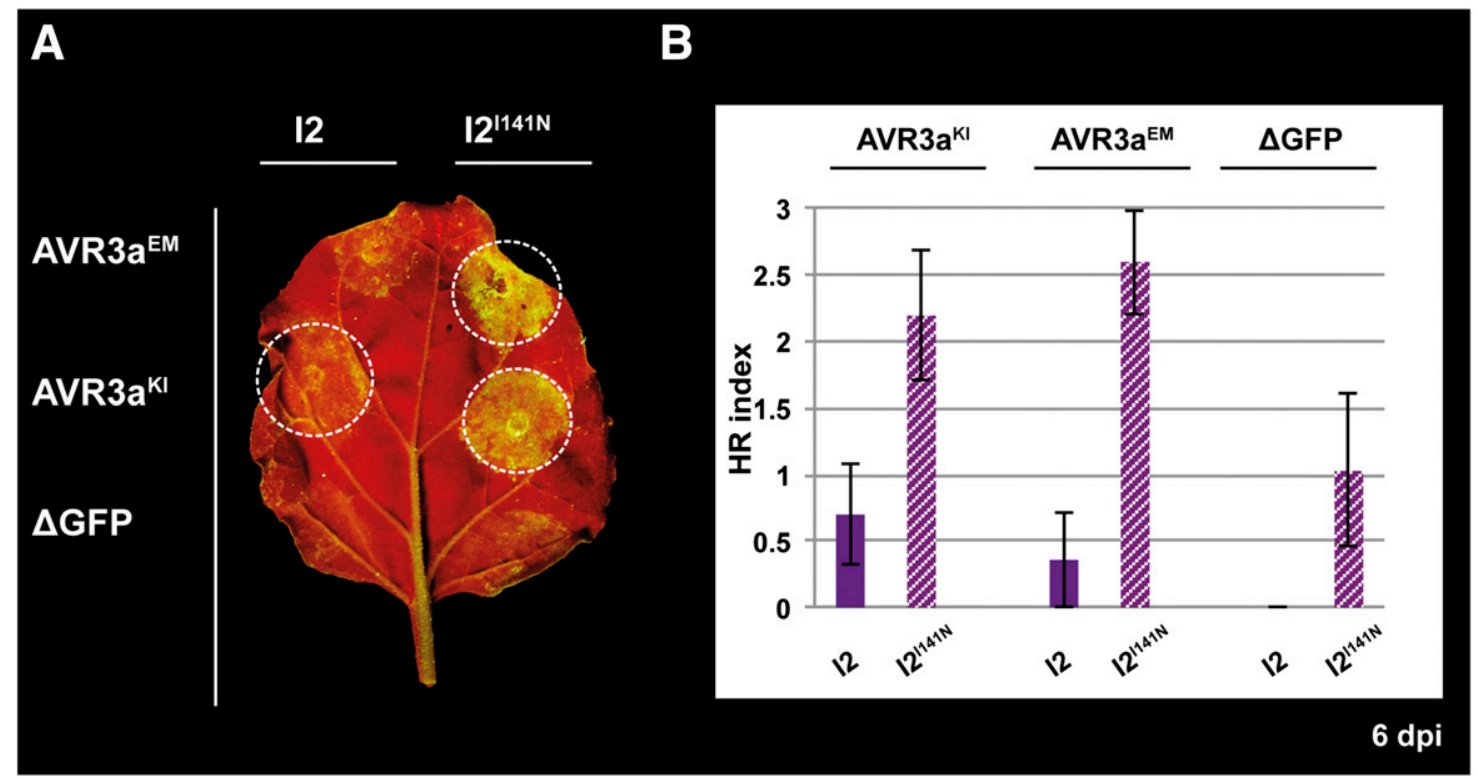

Fig. 5. $\mathrm{I}^{\mathrm{I} 141 \mathrm{~N}}$ responds to AVR $3 \mathrm{a}^{\mathrm{EM}}$ while retaining the response to the AVR $3 \mathrm{a}^{\mathrm{KI}}$ isoform. A, Hypersensitive response (HR) phenotypes of wild-type I2 and $12^{141 \mathrm{~N}}$ after co-expression with the Phytophthora infestans AVR3a variants in Nicotiana benthamiana leaves. The wild-type and mutant $I 2$ were under transcriptional control of the Cauliflower mosaic virus $35 \mathrm{~S}$ promoter and $\mathrm{AVR} 3 \mathrm{a}^{\mathrm{KI}}, \mathrm{AVR} 3 \mathrm{a}^{\mathrm{EM}}$, or a truncated version of green fluorescent protein $(\Delta \mathrm{GFP})$ were expressed from a Potato virus $X$-based vector. The picture was taken at 6 days postinfiltration (dpi). B, HR indices corresponding to the experiment described in A. Values scored at 6 dpi are plotted. Bars represent the average of 20 replicas for each combination of constructs; error bars represent standard deviation.

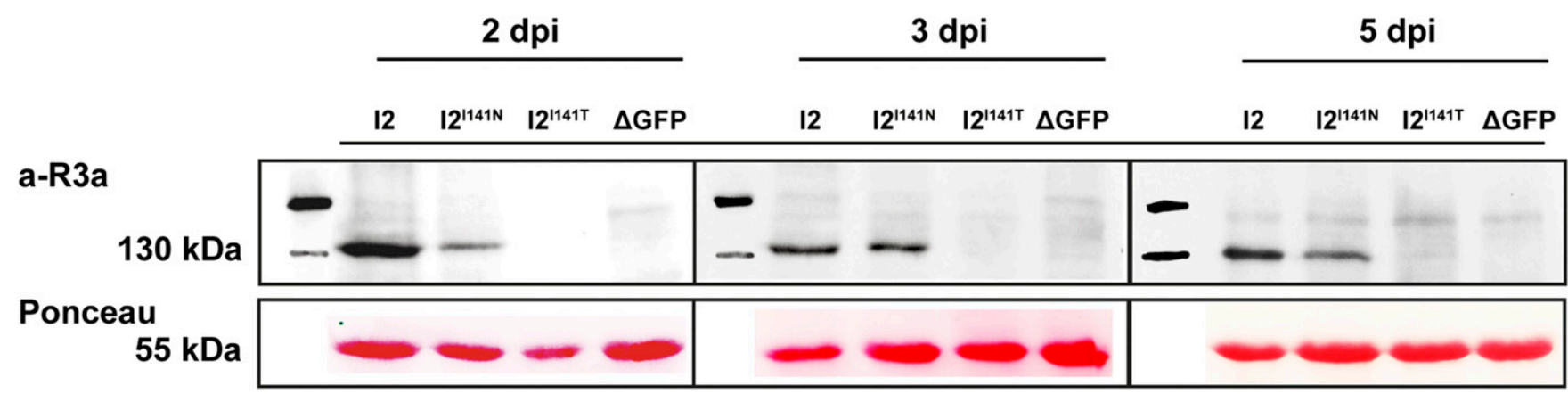

Fig. 6. The $\mathrm{I} 2^{\mathrm{I} 141 \mathrm{~N}}$ gain-of-response mutant has an altered stability compared with wild-type I 2 in planta. Nicotiana benthamiana leaves were agroinfiltrated with constructs to express wild-type and mutant I 2 proteins or a truncated version of green fluorescent protein ( $\Delta$ GFP). Total protein extracts from leaves sampled at 2, 3, and 5 days postinfiltration (dpi) were subjected to sodium dodecyl sulfate polyacrylamide gel electrophoresis followed by immunoblotting with a polyclonal antibody raised against the $\mathrm{CC}$ domain of R3a (a-R3a, upper panel). A band of approximately $145 \mathrm{kDa}$ corresponding to $\mathrm{I} 2 \mathrm{was}$ present in total extracts of the leaves infiltrated with the $I 2$ and $I 2^{I 14 I N}$ constructs. Ponceau S staining of Rubisco (lower panel) is shown as control of the amount of protein loaded and transferred in each lane. Sizes (in kilodaltons) are indicated on the left. I2 ${ }^{\mathrm{I} 141 \mathrm{~T}}$ is a loss-of-response I 2 mutant and was included as an additional negative control in this experiment. Different boxes indicate different blots. 
(Takken and Rep 2010). To achieve this, we co-expressed both I 2 wild-type and $\mathrm{I} 2^{\mathrm{I} 141 \mathrm{~N}}$ mutant proteins with the AVR2 effector variants from $F$. oxysporum $\mathrm{f}$. sp. lycopersici using agroinfiltration in $N$. benthamiana. $\mathrm{I} 2^{\mathrm{I} 141 \mathrm{~N}}$ responded to two of the three stealthy $\mathrm{AVR} 2$ variants-AVR2 $2^{\mathrm{V}}>\mathrm{M}$ (HR index approximately 3 ) and $\mathrm{AVR} 2^{\mathrm{R}}>\mathrm{H}$ (HR index approximately 1.2) — while retaining the capacity to respond to AVR2 from $F$. oxysporum f. sp. lycopersici race 2 (HR index approximately 2.5) (Fig. 8). These results indicate that the gain-of-response mutation identified based on one pathogen effector display also increased the response spectrum to effectors from another pathogen. Therefore, the $\mathrm{I} 2^{\mathrm{I} 141 \mathrm{~N}}$ mutant of $\mathrm{I} 2$ has expanded response to effectors from oomycetes and fungi, two phylogenetically unrelated plant pathogens.

\section{DISCUSSION}

Tomato I 2 and its potato ortholog R3a are two NLR immune receptors that have been previously described to mediate resistance to fungi and oomycetes, respectively (Armstrong et al. 2005; Bos et al. 2006; Ori et al. 1997; Simons et al. 1998; Takken and Rep 2010). We discovered that I2 weakly responds to the AVR $3 \mathrm{a}^{\mathrm{KI}}$ effector from $P$. infestans and also confers resistance to a strain of this pathogen that expresses this effector (Figs. 1 and 7). By using targeted mutagenesis, we recovered a mutant in the $\mathrm{I} 2$ protein, $\mathrm{I} 2^{\mathrm{I} 141 \mathrm{~N}}$, with enhanced response to both AVR $3 \mathrm{a}^{\mathrm{KI}}$ and the stealthy AVR $3 \mathrm{a}^{\mathrm{EM}}$ isoform that is produced by R3a-virulent races of $P$. infestans (Fig. 5). Remarkably, $\mathrm{I} 2^{\mathrm{I} 141 \mathrm{~N}}$ conferred partial resistance to an R3a-breaking strain of $P$. infestans that expresses AVR3 $\mathrm{a}^{\mathrm{EM}}$ (Fig. 7). In addition, $\mathrm{I} 2^{\mathrm{I} 141 \mathrm{~N}}$ showed enhanced response to two of three $F$. oxysporum $\mathrm{f}$. sp. lycopersici AVR2 stealthy variants that evade response by the wild-type I2 (Fig. 8). These findings open up exciting perspectives for the budding field of synthetic NLR-mediated disease resistance (Farnham and Baulcombe 2006; Harris et al. 2013; Segretin et al. 2014). First, knowledge generated on one NLR receptor can be exploited to improve homologous NLR from other plant species. Second, synthetic NLR immune receptors can be engineered to confer resistance to phylogenetically divergent pathogens. Overall, these approaches can be applied to develop synthetic immune receptors that are beneficial to agriculture.

In this study, we focused on two previously identified mutations at the $\mathrm{N}$ terminal part of R3a (R3 $\mathrm{a}^{\mathrm{I} 148 \mathrm{~F}}$ and $\mathrm{R} 3 \mathrm{a}^{\mathrm{N} 336 \mathrm{Y}}$ ) and transferred them to I 2 based on the high level of sequence similarity the two proteins have at this region. The I 2 mutants generated resulted in a loss-of-response $\left(\mathrm{I}^{\mathrm{I141F}}\right)$ and autoactive phenotype $\left(\mathrm{I} 2^{\mathrm{N} 330 \mathrm{Y}}\right)$, respectively. Our knowledge of the underlying mechanisms in the I2 and R3a systems is limited. However, we propose that previous screens (Chapman et al.

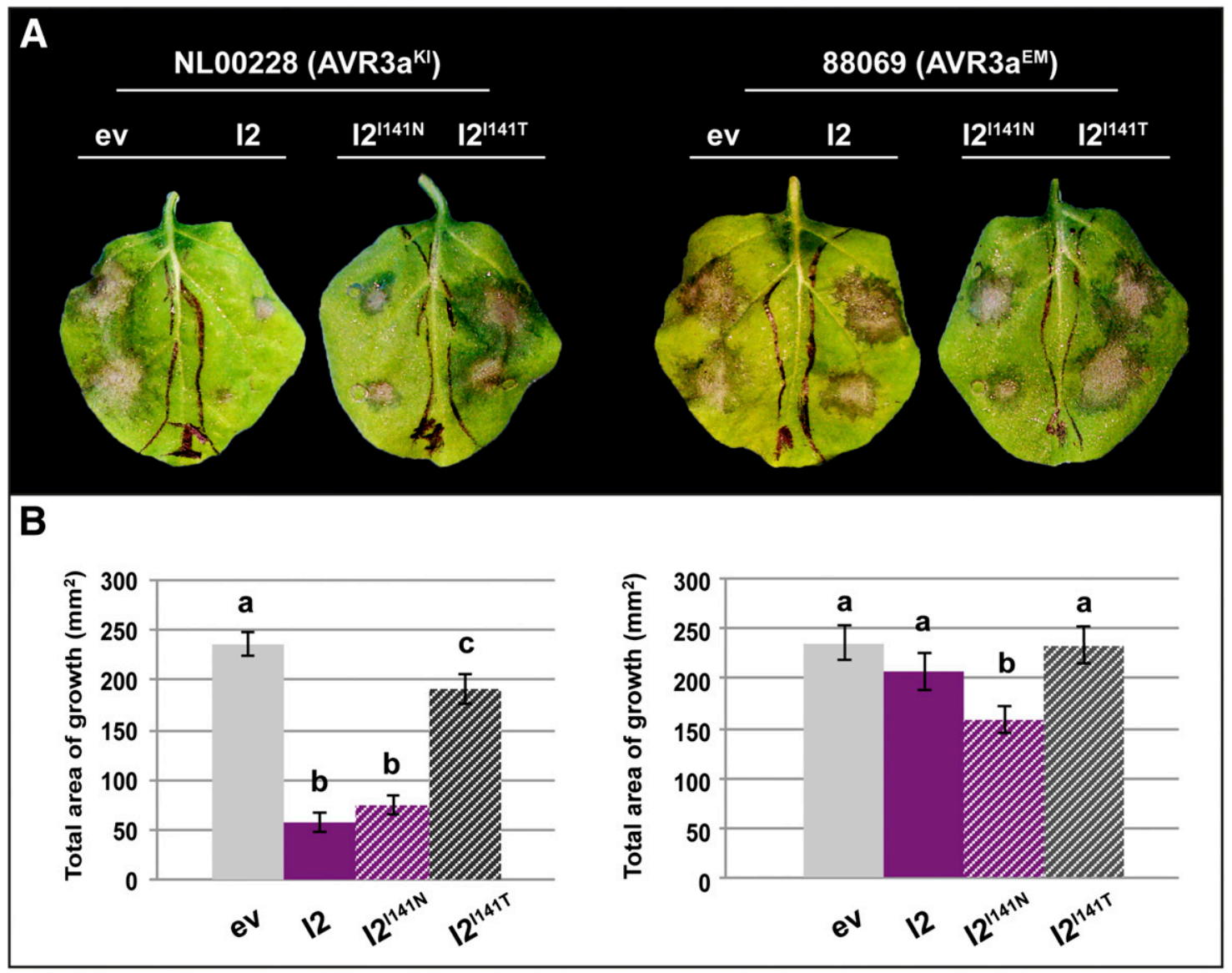

Fig. 7. Wild-type $\mathrm{I} 2$ and $\mathrm{I} 2^{\mathrm{I} 141 \mathrm{~N}}$ confer partial resistance to strains of Phytophthora infestans. A, Wild-type $\mathrm{I} 2$ and $\mathrm{I} 2$ mutants were expressed in Nicotiana benthamiana leaves under transcriptional control of the Cauliflower mosaic virus $35 \mathrm{~S}$ promoter. After approximately $15 \mathrm{~h}$, the infiltrated leaves were drop inoculated with $P$. infestans-zoospore suspensions corresponding to the strains NL00228 (carrying AVR $3 \mathrm{a}^{\mathrm{KI}}$ ) and 88069 (carrying AVR $3 \mathrm{a}^{\mathrm{EM}}$ ). Pictures were taken at 6 days postinoculation (dpi). B, Total area of P. infestans growth was determined with Image J software (Schneider et al. 2012). Values corresponding to 6 dpi are plotted. Bars represent the average of 24 replicas for each treatment; error bars represent standard deviation. The experiment was performed four times and a representative repeat is shown. The Gateway binary vector pK7WG2 was included as negative control (empty vector [ev]). I2 ${ }^{\mathrm{I1} 41 \mathrm{~T}}$ is a loss-of-response I2 mutant and was used as an additional negative control in this experiment. Significant differences between the groups are indicated by letters and were determined in an analysis of variance $(P \leq 0.05)$. 
2014; Segretin et al. 2014) have revealed amino-acid positions that are important for the activity of these NLR receptors. One possibility is that the amino acids surrounding these two positions in the CC and NB-ARC domain of I2 (141 and 330), combined with the introduced substitutions, affect protein activity by preventing interaction with downstream signaling components $\left(\mathrm{I} 2^{\mathrm{I} 141 \mathrm{~F}}\right)$ or by changing the overall conformation of the protein, leading to a constitutive activated state (I2 $\left.{ }^{\mathrm{N} 330 \mathrm{Y}}\right)$. Based on our structural modeling, position 141 of $\mathrm{I} 2$ is located after the structurally defined $\mathrm{CC}$ domain, at an interdomain region between the $\mathrm{CC}$ and NB-ARC regions. Therefore, it is possible that a change in this residue perturbs domain-domain interactions, affecting the function of this region and interfering with the overall performance of the protein. Previous studies have highlighted the involvement of the $\mathrm{CC}$ domain in pathogen perception and downstream signaling (Chen et al. 2012; Hao et al. 2013; Maekawa et al. 2011a; Rairdan and Moffett 2006). Rairdan et al. (2008) have previously proposed that motifs in the CC domain, including the highly conserved EDVID, mediate interactions important for the function of the protein. However, position 141 in the I2 CC domain doesn't appear to be close to the EDVID motif (Fig. 2A); therefore, we cannot be sure about the mechanism underlying the mutation in that position. In the same study, Rairdan et al. (2008) further suggested a model where the signaling activity of the NB domain is defined by the joint function of both the CC and LRR domains and that this regulation is recognition dependent. Therefore, it is also possible that the specific amino-acid change in the CC domain perturbs intramolecular interactions with the LRR domain, thus enhancing the signaling activity of I 2 .
Position 330 is located near the predicted NB pocket of I2 (Fig. 2B). This region is thought to act as a switch between the active and inactive state of NLR proteins (Tameling et al. 2006). In a previous study, Harris et al. (2013) showed that single-amino-acid mutations near the NB pocket of the potato NLR protein Rx enhanced the expanded response conferred by a single mutation in the LRR domain, resulting in resistance to Poplar mosaic virus. However, saturation mutagenesis in position 330 in $\mathrm{I} 2$ did not result in expanded response phenotypes. It is possible that mutations in this position affect the affinity or catalysis of the ATP/ADP nucleotide. Further analysis is required before any firm conclusions can be drawn.

Stirnweis et al. (2014) identified two positions in the NBARC domain of the wheat powdery mildew resistance gene Pm3 that, when mutated, enhance the ability of the protein to trigger cell death in $N$. benthamiana and also result in expanded resistance of the $P m 3 f$ allele in wheat. They further showed that the same mutations affected the activity of another CNL rice immune receptor, Bph14, highlighting the importance of these two amino acids in a distantly related protein (Stirnweis et al. 2014). In addition, Ashikawa et al. (2012), working on two members of the Pik locus in rice, the broad-spectrum Pikml-TS and narrow-spectrum Pikl-KA gene, generated chimeras to identify which domains define the recognition specificity. They found that a combination of the CC-NB of Pikm1-TS and the LRR of Pik1-KA was sufficient for resistance to a blast fungus isolate virulent only to Pik1-KA. Their results suggested that one or more of the polymorphic amino acids in one or both the CC or NBS domain are responsible for the recognition specificity (Ashikawa 2012). Overall, these studies support the view that the N-terminal

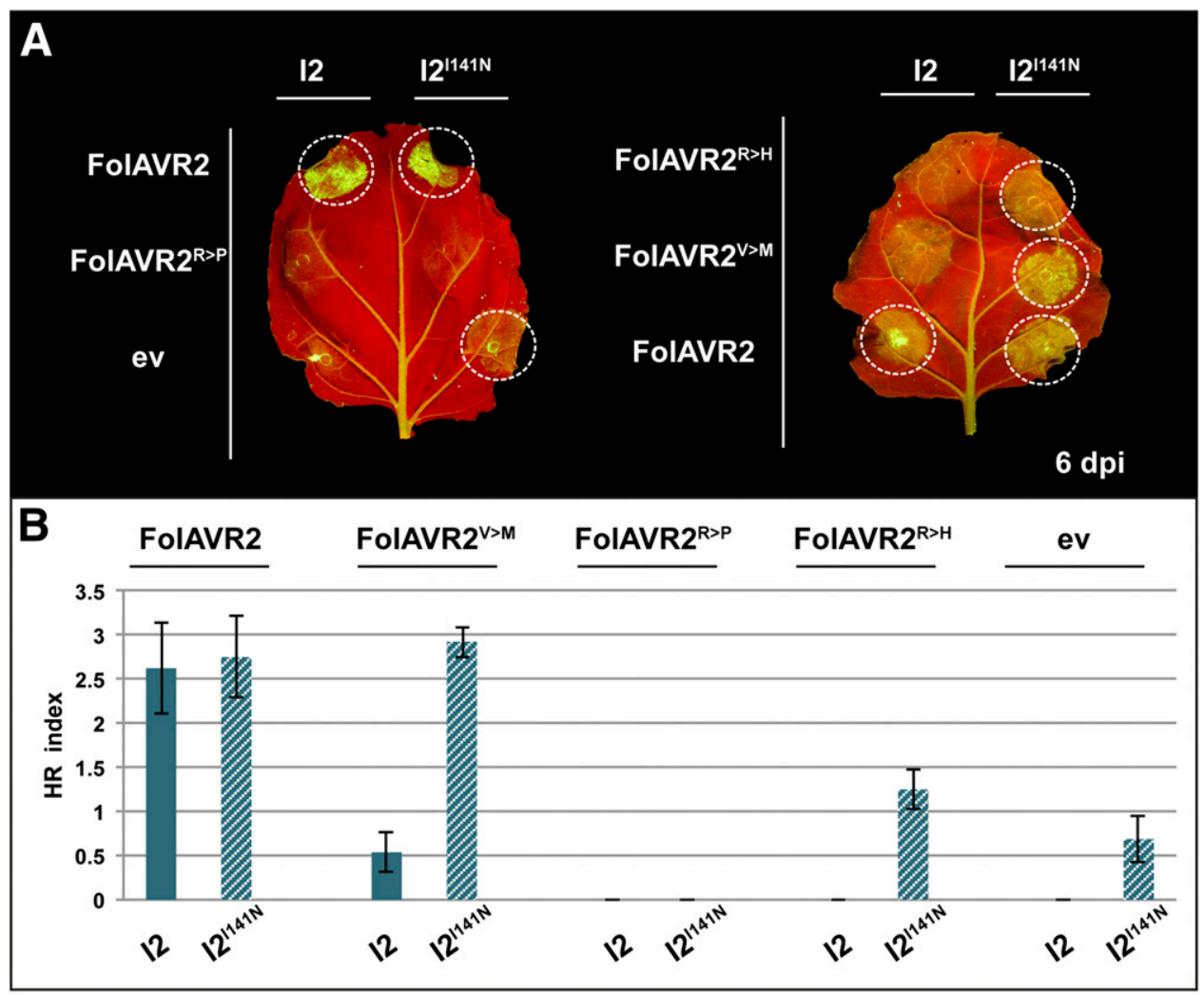

Fig. 8. $\mathrm{I} 2^{\mathrm{I141 \textrm {N }}}$ shows expanded response to Fusarium oxysporum f. sp. lycopersici (Fol) AVR2 variants from race 3. A, Hypersensitive response (HR) phenotypes of wild-type I2 and I $2^{\mathrm{I} 141 \mathrm{~N}}$ after co-expression with the FolAVR2 variants from race 3 in Nicotiana benthamiana leaves. Wild-type and mutant $I 2$ were under transcriptional control of the Cauliflower mosaic virus $35 \mathrm{~S}$ promoter while FolAVR2, FolAVR2 ${ }^{\mathrm{V}>\mathrm{M}}$, FolAVR2 ${ }^{\mathrm{R}>\mathrm{P}}$, and FolAVR2 ${ }^{\mathrm{R}>\mathrm{H}}$ were expressed from the binary vector CTAPi. The CTAPi empty vector (ev) was included as negative control. The picture was taken at 6 days postinfiltration (dpi). $\mathbf{B}, \mathrm{HR}$ indices corresponding to the experiment described in A. Values scored at $6 \mathrm{dpi}$ are plotted. Bars represent the average of 18 replicas for each combination of constructs; error bars represent standard deviation. 
part of NLR protein is implicated in the perception of the pathogen. In conclusion, although our $\mathrm{I} 2^{\mathrm{I} 141 \mathrm{~N}}$ mutant appears to be sensitized, it may also have altered specificity. Future work aiming at identifying the mechanisms mediating the observed expanded response of the $\mathrm{I} 2^{\mathrm{I} 141 \mathrm{~N}}$ mutant protein and also addressing whether this response translates to resistance are required.

Even though transfer to I2 of the precise mutations previously identified in R3a did not yield the desirable phenotype, they helped us focus our screens for improved I 2 mutants. The $\mathrm{I}^{\mathrm{II}}{ }^{\mathrm{I} 1 \mathrm{~N}}$ mutant identified in this study has expanded response to both AVR3a isoforms from P. infestans (Fig. 5) and also to two AVR2 variants from F. oxysporum f. sp. lycopersici race 3 (Fig. 8). However, this mutant also shows a weak HR in the absence of effectors, which suggests that it has increased activation sensitivity. Most likely, this sensitized "trigger-happy" mutant has a lower threshold for activation compared with wild-type I2 and is more easily activated by weak elicitors. This scenario is supported by the expanded response of the $\mathrm{I} 2^{\mathrm{I} 141 \mathrm{~N}}$ to the AVR3a mutants. The altered stability of $\mathrm{I} 2^{\mathrm{I}}{ }^{14 \mathrm{~N}}$ (Fig. 6) is another indication that this mutation affects the overall conformation of the protein that could make it easier for the protein to get activated (Schornack 2006). Another possibility is that the mutated protein has an altered ATP-binding ability. In the wildtype I2 protein, both forms (ATP-bound = "on" and ADP-bound = "off") are kept in a dynamic equilibrium and, in the absence of an elicitor I2, would predominantly be inactive. In a previous study, an autoactive version of $\mathrm{I} 2$ was shown to be impaired in nucleotide hydrolysis (Tameling et al. 2006). A similar mechanism was proposed for an autoactive version of the flax M NLR protein, which shows increased preference for binding ATP (Williams et al. 2011). Further biochemical tests on $\mathrm{I} 2^{\mathrm{I} 141 \mathrm{~N}}$ are required to assess whether this mutation in the N-terminal part of I2 alters the ability of the protein to bind ATP, modifying the threshold for activation.

The pathogenicity assays showed that $\mathrm{I} 2$ confers resistance to a $P$. infestans isolate homozygous for the $A v r 3 a^{K I}$ allele (Fig. 7), suggesting that tomato lines carrying this gene may confer strain-specific resistance to $P$. infestans. However, the level of $\mathrm{HR}$ observed between I2 and AVR $3 \mathrm{a}^{\mathrm{KI}}$ was relatively weak; therefore, we cannot rule out that other effectors present in this $P$. infestans determine the observed I2-mediated resistance. Most late blight lineages infect both potato and tomato (Goodwin et al. 1998), although some lineages primarily infect tomato and are not likely to cause disease on potato plants in the field (Hu et al. 2012). In a later study, Armstrong et al. (2005) screened a selection of 45 P. infestans isolates from Canada, Mexico, the United States, Argentina, Ecuador, Denmark, The Netherlands, and Scotland and found that 40 of them were homozygous for the Avr $3 a^{E M}$ allele, 14 carried both $A v r 3 a^{K I}$ and $A v r 3 a^{E M}$, and only 1 was homozygous for $A v r 3 a^{K I}$. After comparing the genomes of 11 ancient $P$. infestans strains with 15 modern isolates, Yoshida et al. (2013) revealed that the $A v r 3 a^{K I}$ allele was dominant in ancient populations whereas both Avr3a alleles are found in modern isolates, with lineages homozygous for $A v r 3 a^{E M}$ being more common. Even though, in many $P$. infestans populations, the $A v r 3 a^{E M}$ allele dominates, epidemics are often caused by clonal lineages. I2expressing tomato lines may provide some degree of resistance to epidemics caused by strains homozygous for $A v r 3 a^{K I}$; however, these races are rare in modern $P$. infestans populations. Therefore, improved mutants with a broader spectrum of resistance to the dominant $A v r 3 a^{E M}$-carrying $P$. infestans races are needed. The R3a+ mutants previously identified failed to provide resistance against $P$. infestans (Chapman et al. 2014; Segretin et al. 2014). Remarkably, the $\mathrm{I} 2^{\mathrm{I} 141 \mathrm{~N}}$ mutant identified in this study gives partial resistance to $P$. infestans strains carrying either of the $A v r 3 a$ variants in the transient assays used
(Fig. 7). These results suggest that tomato lines carrying the $\mathrm{I}^{\mathrm{I}}{ }^{141 \mathrm{~N}}$ mutant could confer resistance against $P$. infestans.

$N L R$ genes constitute a useful tool for generating sustainable disease-resistant crops. Traditional breeding approaches based on these genes have been used extensively in tomato (Andolfo et al. 2014). Recent transgenic strategies also allow the efficient transfer of $R$ genes between plant species (Horvath et al. 2012; Narusaka et al. 2013; Wulff et al. 2011). However, the deployment of $N L R$ genes through both conventional breeding and transgenic approaches is hampered by the low occurrence of $R$ genes with the useful response specificities. In this study, we show that a synthetically generated NLR mutant protein has expanded response specificities toward two different pathogens. This approach could prove useful for designing and engineering NLR with novel activities, where mutants identified in one gene could be transferred to homologs. Similar to $I 2$ and $R 3 a$, which share a high sequence homology, other $R$ genes with high sequence similarity could benefit from this approach. Such examples are $R P P 8, R C Y 1$, and $H R T$ from Arabidopsis thaliana; Rx and Gpa2 from potato; and Mi-1.2 and Rpi-blb2 from tomato and $S$. bulbocastanum, respectively. Random mutagenesis screens like the one leading to the identification of the R3a+ mutants (Segretin et al. 2014) have been extremely useful in determining critical positions affecting the response profile of $R$ proteins. Recently, the advent of genome editing in plants (Feng et al. 2013; Jiang et al. 2013; Li et al. 2013a; Mao et al. 2013; Miao et al. 2013; Nekrasov et al. 2013; Shan et al. 2013; Xie and Yang 2013) has opened a completely new era in the field of plant biotechnology. The application of genome editing to generate synthetic $R$ genes with expanded response specificities could significantly broaden the perspectives for breeding crop plants with a far-ranging resistance.

\section{MATERIALS AND METHODS}

Microbial strains and growth conditions.

Agrobacterium tumefaciens strain GV3101 (Hellens et al. 2000) and Escherichia coli TOP10 (Invitrogen) were used in molecular cloning experiments and library construction. These strains were cultured as previously described (Sambrook and Russell 2001) at $28^{\circ} \mathrm{C}$ (for GV3101) or $37^{\circ} \mathrm{C}$ (for TOP10) in Luria-Bertani (LB) media supplemented with the appropriate antibiotics. DNA was electoporated into electrocompetent A. tumefaciens GV3101 or transformed by heat shock into competent $E$. coli TOP10 cells following standard protocols (Sambrook and Russell 2001). The following isolates were used in the P. infestans infection assays: NL00228 (Zhu et al. 2012), 88069 (van West et al. 1998), and 88069td (transgenic strain expressing the red fluorescent marker tandem-dimer RFP, known as tdTomato) (Giannakopoulou et al. 2014). Phytophthora strains were grown on rye sucrose agar, as previously described (Kamoun et al. 1998), at $18^{\circ} \mathrm{C}$ in the dark.

\section{Targeted mutagenesis of $I 2$ and $R 3 a$.}

The $I 2$ (GenBank number KR108299) clone was used in this study. The $I 2$ open reading frame was amplified using primers I2G_F and I2G_R (Supplementary Table S1) designed to add a 4-bp (CACC) sequence to the $5^{\prime}$ end of the $I 2$ sequence, which is required for directional cloning, using the $\mathrm{pENTR/D-TOPO}$ cloning kit (Invitrogen). I2 clones with single-residue mutations ( $\mathrm{I} 2^{\mathrm{I} 141 \mathrm{~F}}$ and $\mathrm{I} 2^{\mathrm{N} 330 \mathrm{Y}}$ ) were obtained by inverse polymerase chain reaction (PCR) upon the pENTR::I2 backbone with sets of primers (I141F_F, I141F_R and N330Y_F, N330Y_R) designed to introduce the desired mutations. Random mutagenesis at positions 141 and 330 in the CC and NB-ARC 
domains, respectively, of I2 was performed by inverse PCR upon the pENTR::I2 backbone with sets of degenerate primers (I141×_F, I141F_R and N330×_F, N330Y_R) designed to introduce all possible sequence combinations at these positions. The amplification products were cloned with the pENTR/ D-TOPO cloning kit following standard protocols (Xu and $\mathrm{Li}$ 2008). The Gateway-compatible binary vector pK7WG2 (Karimi et al. 2002) was used as destination for the mutagenized $I 2$ sequences. The $\mathrm{R} 3 \mathrm{a}^{\mathrm{I} 148 \mathrm{~N}}$ clone with a single-residue mutation (I148N) was obtained by GenScript Site-Directed Mutagenesis Service, as described previously (Segretin et al. 2014). The binary vector pCBNptII-vnt1.1P/T-R3a (Segretin et al. 2014) was used as template and destination for the mutagenized $R 3 a$ sequence.

\section{Sequence analyses.}

Plasmid DNA from the $I 2$ mutant clones was isolated and $I 2$ inserts were sequenced by GATC Sequencing Service using several primers to allow full coverage. Base-calling and quality values were obtained using the Phred algorithm (Ewing, Hillier et al. 1998). Sequences were analyzed with MacVector 12.6 (Olson 1994).

\section{Agroinfiltration assays.}

Wild-type and mutant I2 and R3a clones were coagroinfiltrated in $N$. benthamiana leaves to compare their relative response to different effector proteins. Each combination of wild-type or mutant $\mathrm{R}$ protein and effector protein (or negative control) was infiltrated as 16 to 20 replicates per experiment and every experiment was repeated at least three times. Briefly, 10-ml LB media cultures with antibiotics (rifampicin at $50 \mathrm{mg} / \mathrm{liter}$, gentamicin at $20 \mathrm{mg} / \mathrm{liter}$, and spectinomycin at $50 \mathrm{mg} /$ liter [I2 and AVR2 constructs] or ampicillin at $100 \mathrm{mg} /$ liter [R3a and AVR3a constructs]) were inoculated with the library clones and grown at $28^{\circ} \mathrm{C}$ for $48 \mathrm{~h}$ (to reach an optical density at $600 \mathrm{~nm}\left[\mathrm{OD}_{600}\right]$ of 1 to 1.2$)$. Cultures were pelleted by centrifugation $\left(5 \mathrm{~min}\right.$ at $3,500 \mathrm{rpm}$ and $15^{\circ} \mathrm{C}$ ) and resuspended with infiltration buffer $(0.5 \%$ Murashige-Skoog salts medium, $10 \mathrm{mM}$ 2-(N-morpholino)ethanesulfonic acid, $2 \%$ sucrose, and $200 \mu \mathrm{M}$ acetosyringone; $\mathrm{pH} 5.6)$ to a final $\mathrm{OD}_{600}$ of 0.1 . In all the agroinfiltration experiments, pGR106FLAG-AVR3 $\mathrm{a}^{\mathrm{KI}}$ and pGR106-FLAG-AVR $3 \mathrm{a}^{\mathrm{EM}}$ (amino acids 23 to 147) constructs and pGR106-FLAG-AVR $3 a^{\mathrm{E} 80 \times / \mathrm{M} 103}$ or pGR106-FLAG-AVR3a ${ }^{\mathrm{K} 80 \times / \mathrm{I} 103}$ were used to express AVR3a mature proteins (without signal peptide) (Armstrong et al. 2005; Bos 2007; Bos et al. 2006, 2009). A. tumefaciens GV3101 transformed with pGR106- $\Delta$ GFP (containing a truncated version of green fluorescent protein [GFP], as described by Bos and colleagues [2006]) was grown as the AVR3a clones. In addition, CTAPi-AVR2, CTAPi-AVR2 ${ }^{\mathrm{V}>\mathrm{M}}, \mathrm{CTAPi}-\mathrm{AVR} 2^{\mathrm{R}>\mathrm{P}}$, and CTAPi-AVR2 ${ }^{\mathrm{R}>\mathrm{H}}$ (Houterman et al. 2009) were used to express AVR2 mature proteins (without signal peptide). A. tumefaciens GV3101 transformed with CTAPi (Rohila et al. 2004) was grown as the AVR2 clones. For transient co-expression of $R$ gene clones and effector clones, the cells resuspended in infiltration buffer were mixed to have a final $\mathrm{OD}_{600}$ of 0.1 (R clones) and 0.5 (effector clones). Agroinfiltration experiments were performed on 4-week-old $N$. benthamiana plants. Plants were grown and maintained throughout the experiments in a controlled environment room with a temperature of 22 to $25^{\circ} \mathrm{C}$ and high light intensity. HR phenotype development was monitored from 3 to $7 \mathrm{dpi}$ according to an arbitrary scale from 0 (no HR phenotype observed) to 3 (confluent necrosis on the infiltrated area). All the agroinfiltration assays were performed in Norwich, United Kingdom, apart from the assay shown in Supplementary Figure S4 that was performed in Argentina.

\section{Monitoring of HR development.}

$N$. benthamiana agroinfiltrated leaves were examined for HR-associated autofluorescence. For the assays performed in Norwich, we used a Nikon D4 camera with a 60-mm macro lens (ISO set to 1250 or 1600) equipped with a yellow filter (Kodak Wratten number 8). UV Blak-Ray longwave (365nm) lamps B-100AP were spotlights and were moved around the subject during the exposure to give a more even illumination. For the assay performed in Argentina, a UVP.LLC, 8W model UVLMS-38, longwave (365 nm) lamp (Ultraviolet Products) was used and the camera contained no yellow filter. The autofluorescence under exposure to UV light is associated with accumulation of phenolic compounds (Klement et al. 1990).

\section{Infection assays.}

$P$. infestans strains were grown on rye sucrose agar, as described by Kamoun et al. (1998), at $18^{\circ} \mathrm{C}$ in the dark. Spores were harvested as previously described (Kamoun et al. 1998; Schornack et al. 2010) and diluted to 50,000 spores $/ \mathrm{ml}$. Droplets of $10 \mu \mathrm{l}$ were placed onto the abaxial side of 4-week-old detached $N$. benthamiana leaves, approximately $15 \mathrm{~h}$ after previous infiltration with $A$. tumefaciens GV3101 carrying wild-type $\mathrm{I} 2$ or $\mathrm{I} 2$ mutants at a final $\mathrm{OD}_{600}$ of 0.3 . Leaves were incubated for up to 7 days on wet paper towels in trays with $100 \%$ relative humidity. The trays were kept at room temperature. Quantification of the total area of infection was carried out using Image J software (Schneider et al. 2012). Mycelial growth of $P$. infestans strain 88069td was visualized using a Leica Stereomicroscope (Leica Microsystems CMS GmbH) mounted with a CCD camera under UV LED illumination and filter settings for DsRed. In this case, the lesion area was monitored using bioimage analysis software. The software plugin was designed so that it could batch process a series of TIFF microscope images based on a number of core ImageJ/FIJI libraries. The algorithm extracted the intensity plane from the TIFF images, based on which masking methods were applied to identify regions with high intensity and contrast values. Tailored feature selection functions were implemented to detect objects such as the scale (pixel to micrometer) and infection areas on every image. Finally, a two-dimensional convex hull method was applied to measure recognized infection areas and score the size or perimeter of the infection (in both pixels and micrometers).

\section{Western blots.}

Wild-type and mutant I2 and R3a proteins were transiently expressed by $A$. tumefaciens-mediated transformation in $N$. benthamiana leaves, and samples were collected at 2,3, and 5 dpi. Protein extracts were prepared by grinding leaf samples in liquid nitrogen and extracting $1 \mathrm{~g}$ of tissue in $3 \mathrm{ml}$ of GTEN protein extraction buffer ( $150 \mathrm{mM}$ Tris- $\mathrm{HCl}$ [pH 7.5], $150 \mathrm{mM}$ $\mathrm{NaCl}, 10 \%$ [wt/vol] glycerol, and $10 \mathrm{mM}$ EDTA) with freshly added $10 \mathrm{mM}$ dithiothreitol, $2 \%$ (wt/vol) polyvinyl polypyrrolidone, $1 \%$ ( $\mathrm{vol} / \mathrm{vol}$ ) protease inhibitor cocktail (SigmaAldrich), and $1 \%$ (vol/vol) Nonidet P-40, as previously described (Win et al. 2011). Immunoblotting was performed with a polyclonal antibody raised against the CC domain of R3a (a-R3a).

\section{I2 structure predictions.}

Homology models of the individual $\mathrm{CC}$ and NB-ARC regions of I2 were generated using protein fold recognition algorithms, as implemented by four different servers: Intfold2 (Buenavista et al. 2012; McGuffin et al. 2015), iTASSER (Zhang 2008), Phyre2 (Kelley et al. 2015), and SWISSMODEL (Biasini et al. 2014). For the CC domain, three of the prediction programs (iTASSER, Phyre2, and SWISS-MODEL) identified the CC domain of the barley CNL protein MLA10 (PDB code 3QFL) as the top-scoring template for modeling of 
the I2 CC domain. IntFOLD2 (Buenavista et al. 2012; McGuffin et al. 2015) produced a model based on the CC domain of the potato CNL protein Rx (PDB code 4M70), which adopts a distinct structure, quite different at the three-dimensional level from MLA10. The NB-ARC domain was modeled using Apaf-1 (PDB code 1Z6T chain B) (Riedl et al. 2005) as template, which was the top score of IntFold2. That template is in agreement with previously published experimental evidence showing that I2 has ATPase activity (Tameling et al. 2002), as determined by positioning of the key motifs known to be required for ATPases.

\section{ACKNOWLEDGMENTS}

This work was supported by the European Research Council (proposal "NGRB"), the U.K. Biotechnology and Biological Sciences Research Council (grants BB/I019557 and BB/J00453), the John Innes Foundation, and the Gatsby Charitable Foundation. A. Giannakopoulou received support from the Norwich Research Park fellowship and Onassis Foundation. The funders had no role in study design, data collection and analysis, decision to publish, or preparation of the manuscript. We thank F. L. W Takken for providing the $I 2$ and $A V R 2$ clones, V. G. A. A. Vleeshouwers for providing the NL00228 strain, and S. Whisson for providing the 88069td strain.

\section{LITERATURE CITED}

Andolfo, G., Jupe, F., Witek, K., Etherington, G. J., Ercolano, M. R., and Jones, J. D. G. 2014. Defining the full tomato NB-LRR resistance gene repertoire using genomic and cDNA RenSeq. BMC Plant Biol. 14:120.

Armstrong, M. R., Whisson, S. C., Pritchard, L., Bos, J. I. B., Venter, E., Avrova, A. O., Rehmany, A. P., Böhme, U., Brooks, K., Cherevach, I., Hamlin, N., White, B., Fraser, A., Lord, A., Quail, M. A., Churcher, C., Hall, N., Berriman, M., Huang, S., Kamoun, S., Beynon, J. L., and Birch, P. R. J. 2005. An ancestral oomycete locus contains late blight avirulence gene Avr3a, encoding a protein that is recognized in the host cytoplasm. Proc. Natl. Acad. Sci. U.S.A. 102:7766-7771.

Ashikawa, I. 2012. Regions outside the leucine-rich repeat domain determine the distinct resistance specificities of the rice blast resistance genes Pik and Pik-m. Mol. Breed. 30:1531-1535.

Atamian, H. S., Eulgem, T., and Kaloshian, I. 2012. SIWRKY70 is required for Mi-1-mediated resistance to aphids and nematodes in tomato. Planta 235:299-309.

Biasini, M., Bienert, S., Waterhouse, A., Arnold, K., Studer, G., Schmidt, T., Kiefer, F., Cassarino, T. G., Bertoni, M., Bordoli, L., and Schwede, T. 2014. SWISS-MODEL: Modelling protein tertiary and quaternary structure using evolutionary information. Nucleic Acids Res. 42: W252-W258.

Birker, D., Heidrich, K., Takahara, H., Narusaka, M., Deslandes, L., Narusaka, Y., Reymond, M., Parker, J. E., and O'Connell, R. 2009. A locus conferring resistance to Colletotrichum higginsianum is shared by four geographically distinct Arabidopsis accessions. Plant J. 60:602-613.

Bos, J. I. B. 2007. Function, structure and evolution of the RXLR effector AVR3a of Phytophthora infestans. Ph.D. thesis, Ohio State University, Columbus, OH, U.S.A..

Bos, J. I. B., Chaparro-Garcia, A., Quesada-Ocampo, L. M., McSpadden Gardener, B. B., and Kamoun, S. 2009. Distinct amino acids of the Phytophthora infestans effector AVR3a condition activation of R3a hypersensitivity and suppression of cell death. Mol. Plant-Microbe Interact. 22:269-281.

Bos, J. I. B., Kanneganti, T.-D., Young, C., Cakir, C., Huitema, E., Win, J., Armstrong, M. R., Birch, P. R. J., and Kamoun, S. 2006. The C-terminal half of Phytophthora infestans RXLR effector AVR3a is sufficient to trigger R3a-mediated hypersensitivity and suppress INF1-induced cell death in Nicotiana benthamiana. Plant J. 48:165-176.

Bozkurt, T. O., Schornack, S., Banfield, M. J., and Kamoun, S. 2012. Oomycetes, effectors, and all that jazz. Curr. Opin. Plant Biol. 15:483492.

Buenavista, M. T., Roche, D. B., and McGuffin, L. J. 2012. Improvement of 3D protein models using multiple templates guided by single-template model quality assessment. Bioinformatics 28:1851-1857.

Chapman, S., Stevens, L. J., Boevink, P. C., Engelhardt, S., Alexander, C. J., Harrower, B., Champouret, N., McGeachy, K., Van Weymers, P. S. M., Chen, X., Birch, P. R. J., and Hein, I. 2014. Detection of the virulent form of AVR3a from Phytophthora infestans following artificial evolution of potato resistance gene R3a. PLoS One 9:e110158.
Chen, Y., Liu, Z., and Halterman, D. A. 2012. Molecular determinants of resistance activation and suppression by Phytophthora infestans effector IPI-O. PLoS Pathog. 8:e1002595.

Chowdappa, P., Kumar, N. B. J., Madhura, S., Kumar, M. S. P., Myers, K. L., Fry, W. E., Squires, J. N., and Cooke, D. E. L. 2013. Emergence of 13_A2 Blue Lineage of Phytophthora infestans was Responsible for Severe Outbreaks of Late Blight on Tomato in South-West India. J. Phytopathol. 161:49-58.

Cook, R. J. 2000. Advances in plant health management in the twentieth century. Annu. Rev. Phytopathol. 38:95-116.

Cooke, D. E. L., Cano, L. M., Raffaele, S., Bain, R. A., Cooke, L. R., Etherington, G. J., Deahl, K. L., Farrer, R. A., Gilroy, E. M., Goss, E. M., Grünwald, N. J., Hein, I., MacLean, D., McNicol, J. W., Randall, E., Oliva, R. F., Pel, M. A., Shaw, D. S., Squires, J. N., Taylor, M. C., Vleeshouwers, V. G. A. A., Birch, P. R. J., Lees, A. K., and Kamoun, S. 2012. Genome analyses of an aggressive and invasive lineage of the Irish potato famine pathogen. PLoS Pathog. 8:e1002940.

Deslandes, L., Olivier, J., Peeters, N., Feng, D. X., Khounlotham, M., Boucher, C., Somssich, I., Genin, S., and Marco, Y. 2003. Physical interaction between RRS1-R, a protein conferring resistance to bacterial wilt, and PopP2, a type III effector targeted to the plant nucleus. Proc. Natl. Acad. Sci. U.S.A. 100:8024-8029.

Dodds, P. N., and Rathjen, J. P. 2010. Plant immunity: Towards an integrated view of plant-pathogen interactions. Nat. Rev. Genet. 11:539-548.

Ewing, B., Hillier, L., Wendl, M. C., and Green, P. 1998. Base-calling of automated sequencer traces using Phred. I. Accuracy assessment. Genome Res. 8:175-185.

Farnham, G., and Baulcombe, D. C. 2006. Artificial evolution extends the spectrum of viruses that are targeted by a disease-resistance gene from potato. Proc. Natl. Acad. Sci. U.S.A. 103:18828-18833.

Feng, Z., Zhang, B., Ding, W., Liu, X., Yang, D.-L., Wei, P., Cao, F., Zhu, S., Zhang, F., Mao, Y., and Zhu, J.-K. 2013. Efficient genome editing in plants using a CRISPR/Cas system. Cell Res. 23:1229-1232.

Fisher, M. C., Henk, D. A., Briggs, C. J., Brownstein, J. S., Madoff, L. C., McCraw, S. L., and Gurr, S. J. 2012. Emerging fungal threats to animal, plant and ecosystem health. Nature 484:186-194.

Gassmann, W., Hinsch, M. E., and Staskawicz, B. J. 1999. The Arabidopsis RPS4 bacterial-resistance gene is a member of the TIR-NBS-LRR family of disease-resistance genes. Plant J. 20:265-277.

Gebhardt, C., and Valkonen, J. P. T. 2001. Organization of genes controlling disease resistance in the potato genome. Annu. Rev. Phytopathol. 39: 79-102.

Giannakopoulou, A., Schornack, S., Bozkurt, T. O., Haart, D., Ro, D.-K., Faraldos, J. A., Kamoun, S., and O'Maille, P. E. 2014. Variation in capsidiol sensitivity between Phytophthora infestans and Phytophthora capsici is consistent with their host range. PLoS One 9:e107462.

Goodwin, S. B., Smart, C. D., Sandrock, R. W., Deahl, K. L., Punja, Z. K., and Fry, W. E. 1998. Genetic change within populations of Phytophthora infestans in the United States and Canada during 1994 to 1996: Role of migration and recombination. Phytopathology 88:939-949.

Hao, W., Collier, S. M., Moffett, P., and Chai, J. 2013. Structural basis for the interaction between the potato virus $X$ resistance protein $(\mathrm{Rx})$ and its cofactor Ran GTPase-activating protein 2 (RanGAP2). J. Biol. Chem. 288:35868-35876.

Harris, C. J., Slootweg, E. J., Goverse, A., and Baulcombe, D. C. 2013. Stepwise artificial evolution of a plant disease resistance gene. Proc. Natl. Acad. Sci. U.S.A. 110:21189-21194.

Hawkes, J. G. 1990. The Potato: Evolution, Biodiversity and Genetic Resources. Belhaven Press, London.

Hellens, R., Mullineaux, P., and Klee, H. 2000. Technical Focus: A guide to Agrobacterium binary Ti vectors. Trends Plant Sci. 5:446-451.

Hogenhout, S. A., Van der Hoorn, R. A. L., Terauchi, R., and Kamoun, S. 2009. Emerging concepts in effector biology of plant-associated organisms. Mol. Plant-Microbe Interact. 22:115-122.

Horvath, D. M., Stall, R. E., Jones, J. B., Pauly, M. H., Vallad, G. E., Dahlbeck, D., Staskawicz, B. J., and Scott, J. W. 2012. Transgenic resistance confers effective field level control of bacterial spot disease in tomato. PLoS One 7:e42036.

Houterman, P. M., Ma, L., van Ooijen, G., de Vroomen, M. J., Cornelissen, B. J. C., Takken, F. L. W., and Rep, M. 2009. The effector protein Avr2 of the xylem-colonizing fungus Fusarium oxysporum activates the tomato resistance protein I-2 intracellularly. Plant J. 58:970-978.

Hu, C.-H., Perez, F. G., Donahoo, R., McLeod, A., Myers, K., Ivors, K., Secor, G., Roberts, P. D., Deahl, K. L., Fry, W. E., and Ristaino, J. B. 2012. Recent genotypes of Phytophthora infestans in the eastern United States reveal clonal populations and reappearance of mefenoxam sensitivity. Plant Dis. 96:1323-1330. 
Huang, S., van der Vossen, E. A. G., Kuang, H., Vleeshouwers, V. G., Zhang, N., Borm, T. J. A., van Eck, H. J., Baker, B., Jacobsen, E., and Visser, R. G. F. 2005. Comparative genomics enabled the isolation of the R3a late blight resistance gene in potato. Plant J. 42:251-261.

Jacob, F., Vernaldi, S., and Maekawa, T. 2013. Evolution and conservation of plant NLR functions. Front. Immunol. 4:297.

Jiang, W., Zhou, H., Bi, H., Fromm, M., Yang, B., and Weeks, D. P. 2013. Demonstration of CRISPR/Cas9/sgRNA-mediated targeted gene modification in Arabidopsis, tobacco, sorghum and rice. Nucleic Acids Res. 41:e188.

Jones, J. D. G., and Dangl, J. L. 2006. The plant immune system. Nature 444:323-329.

Jones, J. D. G., Witek, K., Verweij, W., Jupe, F., Cooke, D., Dorling, S., Tomlinson, L., Smoker, M., Perkins, S. and Foster, S. 2014. Elevating crop disease resistance with cloned genes. Philos. Trans. R. Soc. B. 369: 20130087.

Kamoun, S., van West, F., Vleeshouwers, V. G., de Groot, K. E., and Govers, F. 1998. Resistance of Nicotiana benthamiana to Phytophthora infestans is mediated by the recognition of the elicitor protein INF1. Plant Cell 10:1413-1426.

Karimi, M., Inzé, D., and Depicker, A. 2002. GATEWAY vectors for Agrobacterium-mediated plant transformation. Trends Plant Sci. 7:193-195.

Kelley, L. A., Mezulis, S., Yates, C. M., Wass, M. N., and Sternberg, M. J. E. 2015. The Phyre2 web portal for protein modeling, prediction and analysis. Nat. Protoc. 10:845-858.

Klement, Z., Rudolph, K., and Sands, D. C. 1990. Methods in Phytobacteriology. Kluwer Academic Publishers, Norwell, MA, U.S.A.

Li, J.-F., Norville, J. E., Aach, J., McCormack, M., Zhang, D., Bush, J., Church, G. M., and Sheen, J. 2013a. Multiplex and homologous recombination-mediated genome editing in Arabidopsis and Nicotiana benthamiana using guide RNA and Cas9. Nat. Biotechnol. 31:688-691.

Li, Y., van der Lee, T., Zhu, J. H., Jin, G. H., Lan, C. Z., Zhu, S. X., Zhang, R. F., Liu, B. W., Zhao, Z. J., Kessel, G., Huang, S. W., and Jacobsen, E. 2013b. Population structure of Phytophthora infestans in China geographic clusters and presence of the EU genotype Blue_13. Plant Pathol. 62:932-942.

Lozano-Torres, J. L., Wilbers, R. H. P., Gawronski, P., Boshoven, J. C., Finkers-Tomczak, A., Cordewener, J. H. G., America, A. H. P., Overmars, H. A., Van 't Klooster, J. W., Baranowski, L., Sobczak, M., Ilyas, M., van der Hoorn, R. A. L., Schots, A., de Wit, P. J. G. M., Bakker, J., Goverse, A., and Smant, G. 2012. Dual disease resistance mediated by the immune receptor $\mathrm{Cf}-2$ in tomato requires a common virulence target of a fungus and a nematode. Proc. Natl. Acad. Sci. U.S.A. 109: 10119-10124.

Maekawa, T., Cheng, W., Spiridon, L. N., Töller, A., Lukasik, E., Saijo, Y., Liu, P., Shen, Q.-H., Micluta, M. A., Somssich, I. E., Takken, F. L. W., Petrescu, A.-J., Chai, J., and Schulze-Lefert, P. 2011a. Coiled-coil domain-dependent homodimerization of intracellular barley immune receptors defines a minimal functional module for triggering cell death. Cell Host Microbe 9:187-199.

Maekawa, T., Kufer, T. A., and Schulze-Lefert, P. 2011b. NLR functions in plant and animal immune systems: So far and yet so close. Nat. Immunol. 12:817-826.

Mao, Y., Zhang, H., Xu, N., Zhang, B., Gou, F., and Zhu, J.-K. 2013. Application of the CRISPR-Cas system for efficient genome engineering in plants. Mol. Plant 6:2008-2011.

McGuffin, L. J., Atkins, J. D., Salehe, B. R., Shuid, A. N., and Roche, D. B. 2015. IntFOLD: An integrated server for modelling protein structures and functions from amino acid sequences. Nucleic Acids Res. 43(W1): W169-W173.

Miao, J., Guo, D., Zhang, J., Huang, Q., Qin, G., Zhang, X., Wan, J., Gu, H., and Qu, L.-J. 2013. Targeted mutagenesis in rice using CRISPR-Cas system. Cell Res. 23:1233-1236.

Michelmore, R. W., Christopoulou, M., and Caldwell, K. S. 2013. Impacts of resistance gene genetics, function, and evolution on a durable future. Annu. Rev. Phytopathol. 51:291-319.

Narusaka, M., Kubo, Y., Hatakeyama, K., Imamura, J., Ezura, H., Nanasato, Y., Tabei, Y., Takano, Y., Shirasu, K., and Narusaka, Y. 2013. Interfamily transfer of dual NB-LRR genes confers resistance to multiple pathogens. PLoS One 8:e55954.

Narusaka, M., Shirasu, K., Noutoshi, Y., Kubo, Y., Shiraishi, T., Iwabuchi, M., and Narusaka, Y. 2009. RRS1 and RPS4 provide a dual Resistancegene system against fungal and bacterial pathogens. Plant J. 60:218-226.

Nekrasov, V., Staskawicz, B., Weigel, D., Jones, J. D. G., and Kamoun, S. 2013. Targeted mutagenesis in the model plant Nicotiana benthamiana using Cas9 RNA-guided endonuclease. Nat. Biotechnol. 31:691-693.

Nombela, G., Williamson, V. M., and Muñiz, M. 2003. The root-knot nematode resistance gene Mi-1.2 of tomato is responsible for resistance against the whitefly Bemisia tabaci. Mol. Plant-Microbe Interact. 16:645649

Olson, S. A. 1994. MacVector: An integrated sequence analysis program for the Macintosh. Methods Mol. Biol. 25:195-201.

Ori, N., Eshed, Y., Paran, I., Presting, G., Aviv, D., Tanksley, S., Zamir, D., and Fluhr, R. 1997. The I2C family from the wilt disease resistance locus I2 belongs to the nucleotide binding, leucine-rich repeat superfamily of plant resistance genes. Plant Cell 9:521-532.

Pan, Q., Wendel, J., and Fluhr, R. 2000. Divergent evolution of plant NBSLRR resistance gene homologues in dicot and cereal genomes. J. Mol. Evol. 50:203-213.

Pang, Y., Bai, X. C., Yan, C., Hao, Q., Chen, Z., Wang, J.-W., Scheres, S. H. W., and Shi, Y. 2015. Structure of the apoptosome: Mechanistic insights into activation of an initiator caspase from Drosophila. Genes Dev. 29:277-287.

Pennisi, E. 2010. Armed and dangerous. Science 327:804-805.

Rairdan, G. J., Collier, S. M., Sacco, M. A., Baldwin, T. T., Boettrich, T., and Moffett, P. 2008. The coiled-coil and nucleotide binding domains of the Potato Rx disease resistance protein function in pathogen recognition and signaling. Plant Cell 20:739-751.

Rairdan, G. J., and Moffett, P. 2006. Distinct domains in the ARC region of the potato resistance protein Rx mediate LRR binding and inhibition of activation. Plant Cell 18:2082-2093.

Riedl, S. J., Li, W., Chao, Y., Schwarzenbacher, R., and Shi, Y. 2005. Structure of the apoptotic protease-activating factor 1 bound to ADP. Nature 434:926-933.

Rohila, J. S., Chen, M., Cerny, R., and Fromm, M. E. 2004. Improved tandem affinity purification tag and methods for isolation of protein heterocomplexes from plants. Plant J. 38:172-181.

Sambrook, J., and Russell, D. W. 2001. Molecular Cloning: A Laboratory Manual. Cold Spring Harbor Laboratory Press, Cold Spring Harbor, NY.

Schneider, C. A., Rasband, W. S., and Eliceiri, K. W. 2012. NIH Image to ImageJ: 25 years of image analysis. Nat. Methods 9:671-675.

Schornack, S. 2006. Struktur, Erkennungsspezifität und Regulationsmechanismus des Resistenzproteins Bs4 aus Tomate. Ph.D. thesis, MartinLuther-University Halle-Wittenberg, Halle, Germany.

Schornack, S., van Damme, M., Bozkurt, T. O., Cano, L. M., Smoker, M., Thines, M., Gaulin, E., Kamoun, S., and Huitema, E. 2010. Ancient class of translocated oomycete effectors targets the host nucleus. Proc. Natl. Acad. Sci. U.S.A. 107:17421-17426.

Segretin, M.-E., Pais, M., Franceschetti, M., Chaparro-Garcia, A., Bos, J. I. B., Banfield, M. J., and Kamoun, S. 2014. Single amino acid mutations in the potato immune receptor R3a expand response to Phytophthora effectors. Mol. Plant-Microbe Interact. 27:624-637.

Shan, Q., Wang, Y., Li, J., Zhang, Y., Chen, K., Liang, Z., Zhang, K., Liu, J., Xi, J. J., Qiu, J.-L., and Gao, C. 2013. Targeted genome modification of crop plants using a CRISPR-Cas system. Nat. Biotechnol. 31:686-688.

Simons, G., Groenendijk, J., Wijbrandi, J., Reijans, M., Groenen, J., Diergaarde, P., Van der Lee, T., Bleeker, M., Onstenk, J., de Both, M., Haring, M., Mes, J., Cornelissen, B., Zabeau, M., and Vos, P. 1998. Dissection of the fusarium 12 gene cluster in tomato reveals six homologs and one active gene copy. Plant Cell 10:1055-1068.

Spoel, S. H., and Dong, X. 2012. How do plants achieve immunity? Defence without specialized immune cells. Nat. Rev. Immunol. 12:89-100.

Stirnweis, D., Milani, S. D., Jordan, T., Keller, B., and Brunner, S. 2014. Substitutions of two amino acids in the nucleotide-binding site domain of a resistance protein enhance the hypersensitive response and enlarge the PM3F resistance spectrum in wheat. Mol. Plant-Microbe Interact. 27:265-276.

Takken, F., and Rep, M. 2010. The arms race between tomato and Fusarium oxysporum. Mol. Plant Pathol. 11:309-314.

Takken, F. L. W., Albrecht, M., and Tameling, W. I. L. 2006. Resistance proteins: Molecular switches of plant defence. Curr. Opin. Plant Biol. 9: 383-390.

Takken, F. L. W., and Goverse, A. 2012. How to build a pathogen detector: Structural basis of NB-LRR function. Curr. Opin. Plant Biol. 15:375-384.

Tameling, W. I. L., Elzinga, S. D. J., Darmin, P. S., Vossen, J. H., Takken, F. L. W., Haring, M. A., and Cornelissen, B. J. C. 2002. The tomato $R$ gene products I-2 and MI-1 are functional ATP binding proteins with ATPase activity. Plant Cell 14:2929-2939.

Tameling, W. I. L., Vossen, J. H., Albrecht, M., Lengauer, T., Berden, J. A., Haring, M. A., Cornelissen, B. J. C., and Takken, F. L. W. 2006. Mutations in the NB-ARC domain of I-2 that impair ATP hydrolysis cause autoactivation. Plant Physiol. 140:1233-1245.

van Ooijen, G., Mayr, G., Kasiem, M. M. A., Albrecht, M., Cornelissen, B. J. C., and Takken, F. L. W. 2008. Structure-function analysis of the NB-ARC domain of plant disease resistance proteins. J. Exp. Bot. 59: 1383-1397. 
van Ooijen, G., van den Burg, H. A., Cornelissen, B. J. C., and Takken, F. L. W. 2007. Structure and function of resistance proteins in solanaceous plants. Annu. Rev. Phytopathol. 45:43-72.

van West, P., de Jong, A. J., Judelson, H. S., Emons, A. M. C., and Govers, F. 1998. The ipiO gene of Phytophthora infestans is highly expressed in invading hyphae during infection. Fungal Genet. Biol. 23:126-138.

Vaughn, D. E., Rodriguez, J., Lazebnik, Y., and Joshua-Tor, L. 1999. Crystal structure of Apaf-1 caspase recruitment domain: An alphahelical Greek key fold for apoptotic signaling. J. Mol. Biol. 293:439-447.

Williams, S. J., Sornaraj, P., deCourcy-Ireland, E., Menz, R. I., Kobe, B., Ellis, J. G., Dodds, P. N., and Anderson, P. A. 2011. An autoactive mutant of the $\mathrm{M}$ flax rust resistance protein has a preference for binding ATP, whereas wild-type M protein binds ADP. Mol. Plant-Microbe Interact. 24:897-906.

Win, J., Chaparro-Garcia, A., Belhaj, K., Saunders, D. G. O., Yoshida, K., Dong, S., Schornack, S., Zipfel, C., Robatzek, S., Hogenhout, S. A., and Kamoun, S. 2012. Effector biology of plant-associated organisms: Concepts and perspectives. Cold Spring Harb. Symp. Quant. Biol. 77:235-247.

Win, J., Kamoun, S., and Jones, A. M. E. 2011. Purification of effectortarget protein complexes via transient expression in Nicotiana benthamiana. Methods Mol. Biol. 712:181-194.

Wulff, B. B. H., Horvath, D. M., and Ward, E. R. 2011. Improving immunity in crops: New tactics in an old game. Curr. Opin. Plant Biol. 14:468-476.
Xie, K., and Yang, Y. 2013. RNA-guided genome editing in plants using a CRISPR-Cas system. Mol. Plant 6:1975-1983.

$\mathrm{Xu}, \mathrm{R}$., and Li, Q. Q. 2008. Protocol: Streamline cloning of genes into binary vectors in Agrobacterium via the Gateway(R) TOPO vector system. Plant Methods 4:4.

Yan, N., Chai, J., Lee, E. S., Gu, L., Liu, Q., He, J., Wu, J. W., Kokel, D., Li, H., Hao, Q., Xue, D., and Shi, Y. 2005. Structure of the CED-4-CED-9 complex provides insights into programmed cell death in Caenorhabditis elegans. Nature 437:831-837.

Yoshida, K., Burbano, H. A., Krause, J., Thines, M., Weigel, D., and Kamoun, S. 2014. Mining herbaria for plant pathogen genomes: Back to the future. PLoS Pathog. 10:e1004028.

Yoshida, K., Schuenemann, V. J., Cano, L. M., Pais, M., Mishra, B., Sharma, R., Lanz, C., Martin, F. N., Kamoun, S., Krause, J., Thines, M., Weigel, D., and Burbano, H. A. 2013. The rise and fall of the Phytophthora infestans lineage that triggered the Irish potato famine. eLife 2:e00731.

Zhang, Y. 2008. I-TASSER server for protein 3D structure prediction. BMC Bioinformatics 9:40.

Zhu, S., Li, Y., Vossen, J. H., Visser, R. G. F., and Jacobsen, E. 2012. Functional stacking of three resistance genes against Phytophthora infestans in potato. Transgenic Res. 21:89-99. 